\title{
Kāma at the Kadamba Court
}

\section{The Gudnäpur Pillar Inscription of Ravivarman as a Text-Monument}

\author{
Elizabeth A. Cecil | ORCID: 0000-0002-9205-4916 \\ Florida State University, Tallahassee, FL, USA \\ eacecil@fsu.edu \\ Mekhola Gomes | ORCID: 0000-0002-8034-4254 \\ Durham University, Durham, UK \\ mekhola.gomes@gmail.com
}

\begin{abstract}
In March 1971, B.R. Gopal discovered a partially buried pillar with visible inscribed writing in the village of Guḍnāpur in Karnataka. The monument has since become known as the Guḍnāpur Pillar Inscription of Ravivarman (ca. 465-500 CE) after the ruler of the early Kadamba kingdom who commissioned it. The inscription preserves a compelling historical record that details the intersections of religious and political performance at the Kadamba court as centered around a temple to Kāma constructed within the confines of the royal residence at Vaijayantì (Banavasi), and the distribution of agrarian lands to support its maintenance. This study presents a new translation and analysis of the text and a discussion of the pillar as a 'text-monument' that was both embedded within and constitutive of landscapes: physical and built as well as rhetorical and imagined. By presenting the Guḍnāpur inscription as a text-monument situated within multiple landscapes, the article reveals how documentary, donative, religious, and agrarian practices supported state-making in an early South Indian kingdom.
\end{abstract}

\section{Keywords}

epigraphy - land-grants - royal genealogy - Karnataka - Kāma - Hinduism - temple worship - donative practice - South India 


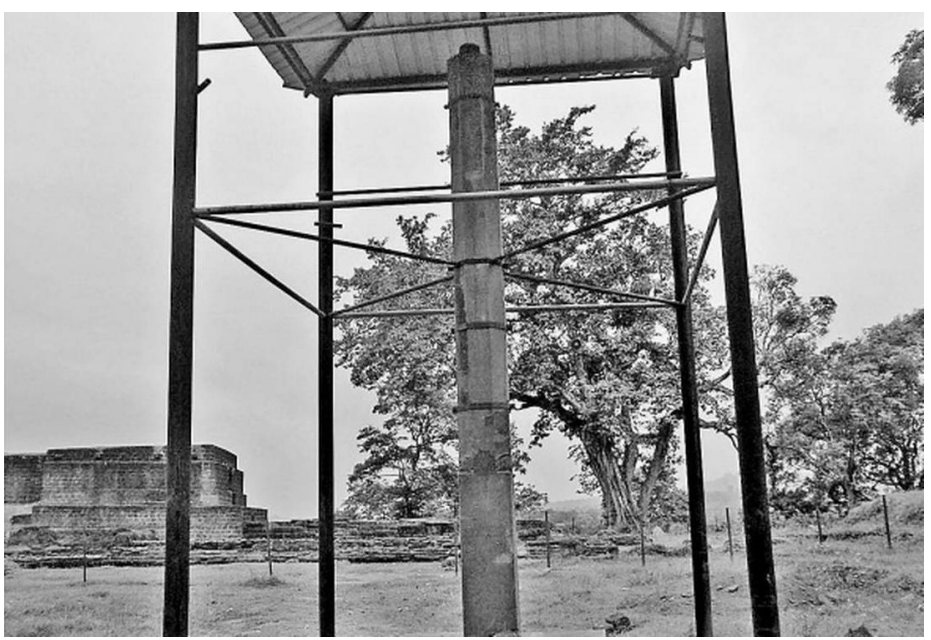

FIGURE 1 Remains of Guḍnāpur Pillar

\section{Introduction}

In March 1971, B.R. Gopal and A. Sundara visited Guḍnāpur, ${ }^{1}$ a village located in the Sirsi Tehsil of the Uttara Kannada District of western Karnataka, to survey the area's historical remains. ${ }^{2}$ During this visit, Gopal found a partially buried stone pillar with visible inscribed writing. This piqued the scholars' interest and the object was excavated from the ground. The broken pillar then lay on its side until 2015, when it was set upright and placed under a roofed shed by the Archaeological Survey of India (ASI) [Figure 1]. ${ }^{3}$ Two years after its initial discovery, Gopal published the first edition of the inscription along with estampages [Figure 2]. ${ }^{4}$ A second, more complete, edition was published by G.S. Gai in 1996 as part of his collection of the inscriptions of the early Kadambas. ${ }^{5}$ Based on paleographic analysis of the southern Brāhmī script in which the record was composed, the inscription was dated to the early sixth century CE. The monument has since become known

$1 \quad 14.5481^{\circ} \mathrm{N}, 74.9815^{\circ} \mathrm{E}$.

2 B.R. Gopal (1973), 61.

3 "Kadamba-era pillar inscription in Gudnapur gets a roof," last modified July 25, 2015, accessed July 13, 2020, http://www.thehindu.com/news/national/karnataka/kadambaera-pillar-inscr iption-in-gudnapur-gets-a-roof/article7462793.ece.

4 Gopal (1973), 61-72 and Plate XI.

5 G.S. Gai (1996), 107-111. 

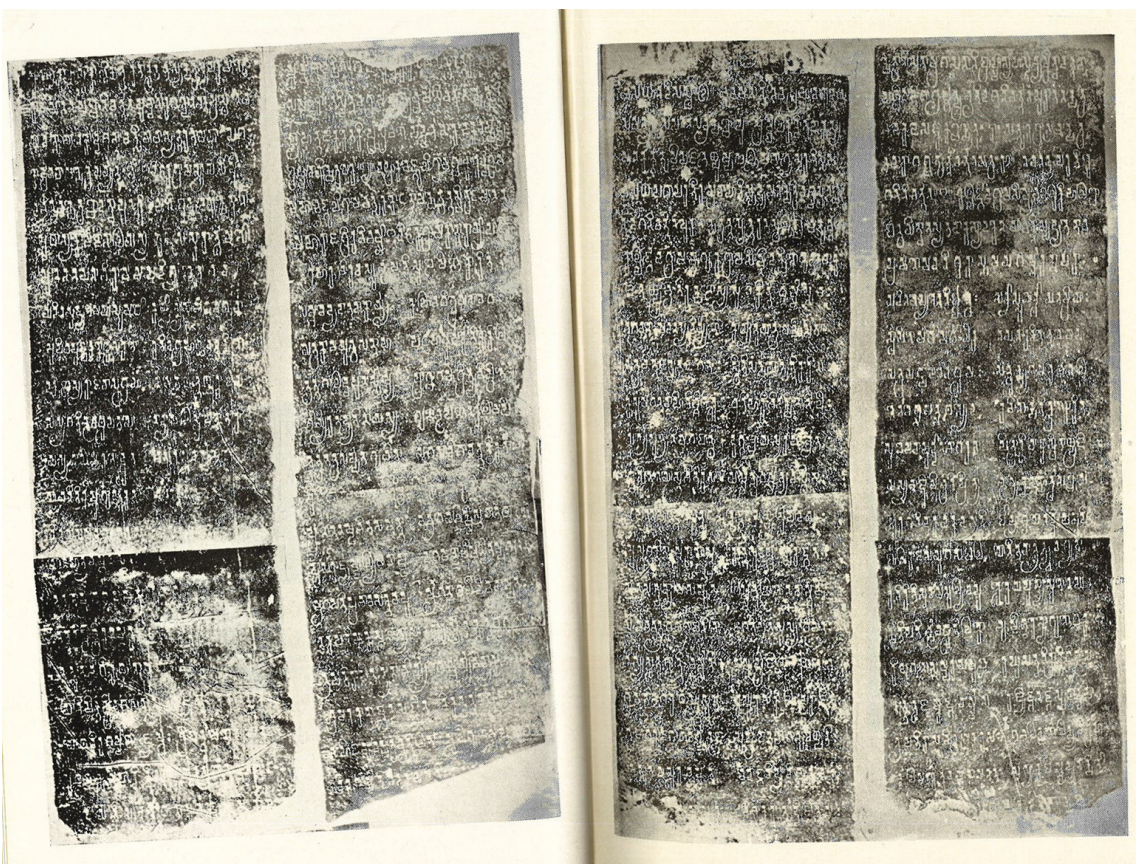

FIGURE 2 Estampage of Guḍnāpur Pillar Inscription AFTER GOPAL, 1973

as the Guḍnāpur Pillar Inscription of Ravivarman (ca. 465-500 CE) after the ruler of the early Kadamba kingdom (ca. 300-6oo CE) who commissioned it. ${ }^{6}$

As primary historical sources, inscriptions blur the boundaries between object, artifact, and text. ${ }^{7}$ Attentive to both the material and the literary dimensions of the inscription and the dynamic interplay between them, this study presents the pillar inscription as a 'text-monument' that was both embedded within and constitutive of landscapes: physical and built as well as rhetorical and imagined. By physical landscapes, we refer to the architectural and agrarian contexts of the inscription. More specifically, the text describes the endowment of a temple to the god Kāma, located within the royal residential complex, and details the donations of land offered to support its maintenance. In addition

6 The appellation 'early' distinguishes this Kadamba lineage from later dynasties also called Kadamba who were subordinates of the Cālukyas of Kalyāna. The later Kadambas ruled over Hangal in Dharwad, Karnataka as well as the region around Goa from the late-tenth to the thirteenth centuries CE. The chronology of early Kadamba rule adopted in this essay follows G.S. Gai (1996).

7 Morrison and Lycett (1997); Trautmann and Sinopli (2002); Orr (2006). 
to these contexts, the pillar was also integral to the rhetorical mapping of the early Kadamba kingdom and the genealogy of its rulers. The creators of the textmonument drew upon existing epigraphic and memorial practices involving pillars, Sanskrit literary tropes, and genealogical structures to craft the 'official history' of the early Kadambas at Guḍnāpur. Analysing the Guḍnāpur inscription as a text-monument situated within multiple landscapes reveals how documentary, donative, religious, and agrarian practices served larger political processes of state-making in the early Kadamba kingdom.

In an effort to recover some of the socio-political practices that shaped the early Kadamba polity, this article presents a new translation of the epigraphic text accompanied by an historical study that situates the inscribed pillar within the larger physical and rhetorical landscapes in which it functioned. Given the richness of the early Kadamba epigraphic corpus - a collection that includes more than forty-four inscriptions on stone and copper-plates composed between the fourth-seventh century CE-our study is far from exhaustive. The Guḍnāpur inscription, however, has remained a relatively unknown text for scholars outside the narrow field of Kadamba studies (especially when compared with the more well-known Tālaguṇ̣a pillar). Through careful attention to a discrete and understudied object, we initiate a larger project on the Kadambas that reexamines the so-called 'Classical Age' of the Gupta Period from the perspective of a South Indian kingdom. In doing so, this study complicates the established historiographical narratives using evidence from a contemporaneous, yet marginalized, polity.

Introducing Object \& Text

The Guḍnāpur inscription is carved on a twenty-foot-high stone column. The object is square-shaped up to a height of sixteen feet after which it is octagonal. The top of the pillar is broken and lost, but the visible tenon indicates that it would have supported a crowning element, likely a makara, the emblem of Kāma, the deity whose temple is commemorated in the inscription. The epigraphic text, engraved in 27 lines, begins at the base and ascends the object. Each line of text wraps around all four sides of the pillar, and every consecutive line is engraved on top of the previous one. All lines begin on the same face of the pillar. Lines $23-27$ are engraved on a single face of the octagonal portion of the column. ${ }^{8}$

8

Gopal (1973), 61. 
As a textual composition, the Guḍnāpur inscription is divided into two sections: the metrical portion, comprised of 30 verses, and the prose section containing 10 lines. The presentation of the text that follows is based primarily on the most recent and complete edition and estampage published by G.S. Gai in 1996. ${ }^{9}$ We have also consulted the earlier edition of B.R. Gopal. ${ }^{10}$ The text of the Guḍnāpur pillar, along with a number of other Kadamba inscriptions, has also been published by Dániel Balogh on the Siddham database and follows Gai's edition. ${ }^{11}$ In presenting the text, we have included the proposed editorial conjectures by Gai based on his readings. ${ }^{12}$ In addition, we have introduced some new emendations in instances where the reported reading presents syntactical issues that make it difficult to make sense of the text as recorded. These changes are accompanied by explanatory notes. An initial translation of the inscription was published by Gopal in 1985 but there have been no further attempts. ${ }^{13}$ While Gopal's translation is helpful in some respects, he glosses over many compounds and leaves untranslated difficult sections of the text. We have included the first complete and annotated translation of the Guḍāpur inscription as part of this study.

\subsection{Summary of the Text}

The metrical section of the inscription begins with a verse in Mālinı̄ invoking Kāmadeva. This introductory verse is followed by 28 verses in Mātrāsamakaviśeșa-a meter comprised of four pādas containing 15 morae each. Verses 222 include a lengthy genealogy of the Kadamba rulers that culminates with a eulogy of Ravivarman, the reigning king at the time of the inscription's composition, in an extended description by relative pronouns in verses 17-22. Verses 22-30 announce the endowment of a temple of Kāmadeva in the royal capital and describe the performance of the annual Spring Festival and procession. The verse portion ends with an injunction in Prthvi meter that future kings respect and maintain the temple.

Since the stone of the pillar is damaged in multiple places, the epigraphic text suffers from a number of lacunae. In addition to the first verse, nine of the

\footnotetext{
9 Gai (1996), 107-111; Plates XXII i-iv.

10 Gopal (1973), 61-72; Plate XI.

11 Balogh (2017). https://siddham.network/inscription/guḍnapur-grant-of-ravivarman/.

12 The published estampage that accompanies Gai's edition (see Figure 2) is difficult to read and use productively as a reference. Further study of this inscription will include fieldwork to view and photograph the stone as well as to access archival images and impressions in Mysore. Any significant improvements to the edition must await this further study.

13 Gopal (1985), 81-91.
} 
verses are incomplete. In the presentation of the text below, we have marked the missing sections in verses 2-29 with ellipses in brackets [...] and included a number in the brackets that indicates the total missing morae. In cases where there are multiple sections of text missing, the total number is given in the final set of bracketed ellipses.

The first portion of the prose section (lines 17-22) is well-preserved, and we have presented the text and translation in full. Line 17 mentions additional donations of villages and cultivable land that Ravivarman donated to support ritual performances at the temple. In line 18, the text begins a separate list that provides details of additional donations of villages, land, and water tanks that were given as brahmadeyas by Ravivarman. In total, nine such gifts are recorded in the inscription as individual entries marked by numerals 1-9 (this numbering is also indicated in our presentation of the text and translation). These kinds of 'prose maps', which are not unlike the land terrier of deeds, can be challenging to connect to contemporary geography. It is often difficult to identify correspondences between locales mentioned in early inscriptions and modern maps since the inscriptions reflect a particular local and situated knowledge and presume the same 'on the ground' perspective from their audience. In the present case, however, the names of many of the ancient villages are reflected in their modern names. Bhat's study of the geography of the inscription has shown that most of the villages were not far from Guḍnāpur (i.e. within 10 $\mathrm{kms}){ }^{14}$ The lands were also widely distributed to the north, south, and west, making Guḍnāpur the center of an expansive agricultural area administered by the Kadamba polity. Notably, Bhat mentions that the Guḍda-tațāka (Guḍḍa Tank) reportedly commissioned by Ravivarman is still in use and the site of an eponymous village. ${ }^{15}$

The inscription concludes with an additional section of prose recorded in lines $23^{-27}$. This portion of the text is badly damaged, but appears to record some further donations of land to the Kāma temple, as well as to a second temple dedicated to the goddess Padmāvatī. It is uncertain if the donor in this case is the king or if this section represents a subsequent donation by a separate individual or group connected to the court. One indication that these donations may have been added later or were undertaken by a different individual is the placement of the text: lines $23-27$ are engraved on a single face of the octagonal portion of the pillar. The presentation of these lines as a discrete section of text might also indicate that they are in some way distinct from the rest

\footnotetext{
14 H.R. Bhat (1978).

15 According to Bhat, this tank is one of the largest in the North Kanara district. The name "Gudda" is likely derived from its surrounding guddas (hills). Bhat (1978), 26-27.
} 
of the prose section. Given the fragmentary state of this part of the inscription, we have provided the surviving text and an annotated summary, rather than attempting a full translation.

jayati suravadhūnāṃ manmathạ̣ kāminīnām

UUUUUU _-_ U__ U_-_ /

UUUUUU____ U_-_tarājyo

UUUUUU_myajyākiṇaśyāmabāhuh //1// (Mālin̄̄)

1. Victory to the "Stirrer of Hearts" (Manmatha) of the wives of the gods, full of desire $[\ldots]$ whose kingdom $[\ldots]$ whose arms are dark with scars from the bowstring. ${ }^{16}$

atha babhūva häritīputro mānavyagotrodbhavo dvijah /

vīraśarmmeti vedakulamatị tā $[\ldots]$ ti $[\ldots 5 \ldots]$ veśmākarot ${ }^{17} / / 2$ //

2. Now there was a brahmin, Vīraśarman, the Son of Hāritī, born in the lineage of Mānavya, whose mind was focused on the collections of Vedas [...] he made a dwelling. ${ }^{18}$

16 This first verse is fragmentary and difficult to construe in total. The invocation is clearly to Kāmadeva, the deity whose temple is commissioned by the ruler Ravivarman later in the record. In addition to the reference to the deity, the poet may have also intended a double meaning that could apply to the king as well. In this case, we can understand Ravivarman as the one who 'stirs the hearts' of the wives of heroes or rival kings (sura). The verse seems to allude to aspects of Kāma's physical appearance and iconographic attributes—notably his arms which have been marked or scarred by the use of his signature bow with its five flower-arrows. These descriptions could, likewise, be applied to Ravivarman. On visual representations of Kāma see Benton (2006), 11-20.

17 As explained above, the missing sections of text in verses 2-29 are indicated with ellipses in brackets [...] with a number indicating the number of total missing morae. In cases where there are multiple sections of text missing, the number is given in the final set of bracketed ellipses.

18 This veśman (dwelling) appears to be a kind of lineage dwelling or established residence that formed the nucleus of what would become the Kadamba polity. The earlier Tālagunḍa Pillar Inscription of Śāntivarman (c. mid-5th century) also alludes to a family compound which was renowned as a center of Vedic learning and Brahmanical authority. It was in the courtyard of this home that a Kadamba tree grew and was lovingly tended by the family. As a result, the tree became their namesake and lineage emblem. On this inscription see 


\section{[...22...]sa dvijottamah /}

kulam abhūt kadambanāma tatas tasyārkkabimbadyutikșitau // 3 //

3. A most excellent brahmin [...] thereupon, from him, came a lineage by the name of Kadamba on the earth which shone like the orb of the sun. ${ }^{19}$

\section{yo 'tha vīraśarmmano jyeșțah śrībandhuṣeṇah priyātmajaḥ / sa hi babhūva kșatravrttilatāmūlagunāmbuprasecitā $\bar{a}^{20} / / 4 / /$}

4. The beloved eldest son of Vìraśarman was śrí-Bandhuṣenaa, ${ }^{21}$ who sprinkled the root of the vine ${ }^{22}$ of warrior conduct with the water of his virtues.

\section{tatsuto mayūravarmmeti vedavedāngavidyāviśāradah / nrpatir āsa vikramaikarasậ śubhalakṣaṇalakșavigrahah // 5 //}

5. His son was Mayūravarman, skilled in knowledge of the Vedas and the Vedāngas. He was a king who found pleasure solely in heroism, (and) whose body was marked with auspicious attributes.

Gai (1996), no. 64; Kielhorn (1905-19o6), v. 4-8. On this inscription for the history of the Kadamba lineage, see also Gomes (2017).

19 The poet's description of the resplendent lineage plays upon the familiar use of images of fire and light to express the power of rulers. See, Gonda (1956), 6o-61. In addition to this trope, the reference to the orb of the sun may also allude to the appearance of the lineage's namesake Kadamba tree. In full bloom, the tree is covered with round yellow flowers. https://en.wikipedia.org/wiki/Neolamarckia_cadamba\#/media/File:Neolamarckia_Cada mba_Flower.jpg.

20 Gai, Gopal, and Balogh read prasecitah. To make better sense of the compound we have tentatively corrected the verse to read prasecitā. The passive prasecitah, when translated, would mean Bandhuṣena was one 'sprinkled by the water of virtues at the root of the vine of warrior conduct'. Emending the reading to the agentive noun prasecitr permits what was likely the intended image: namely, that Bandhuṣena was the one who 'sprinkled the root of the vine of the warrior ethos with the water of his virtues'

21 The Halsi Copper Plates of Ravivarman also include a reference to Bandhușena in which he is identified as the progenitor of a line of Jain temple officiants with names ending in -sena and -kirti. It is also worth noting that Bandhuṣena's name does not follow the convention of his predecessors with names ending in -śarman, likely an indication of brahmin identity. His successors, by contrast, have names ending in -varman, as was widely adopted by rulers. On the Halsi Plates, see Gai (1996), no. 23; Fleet, (1877); Bisschop and Cecil (forthcoming). On the shifting patterns in Kadamba royal titles see Sohoni (1983), 293298.

22 This verse is an example of the organic vine and tree imagery that the poet uses repeatedly in the descriptions of the lineage. Here the reference to Bandhusena being sprinkled or anointed by the water that fed the vine of warrior conduct (kșatravrtti) could be a 
yo 'bhișiktas tridaśasenānyā rājye [...3...] kaikabandhunā /

bhramarakāntābṛndasañgìtavikasannavāmbhojayoninā // 6 //

6. He was anointed in sovereignty by the general of the (thirty) gods (i.e. Skanda) $[\ldots]$ by every single kinsman ${ }^{23}[\ldots]$ by the source of the fresh lotus blossoming with the music from a chorus of female bees (?). ${ }^{24}$

\section{bhujagarājabhogadīrgghabhujaḥ suhṛdāttabhogo bhuvaḥ patiḥ / tattanūjah kañgavarmā sa rājyāingabhañgas sadā dvișām // 7 //}

7. His son was Kangavarman, ${ }^{25}$ whose long arms were like the expanded coil of the king of snakes; a lord of the earth who enjoyed gifts received from friends; the perpetual breaker of the limbs of sovereignty'26 of his enemies.

metaphor used to explain a potentially significant shift in social status from brahmin to kșatriya. We can also read this public shift in the changing names of the earliest rulers: the ending -śarman (traditionally brahmin) is abandoned in favor first of -sena and, finally, the ending -varman common to many ruling lineages in both South and Southeast Asia. In this record, the poet is clearly intent upon praising the brahmin origins of the family (a theme that emerges even more prominently in the Tạlaguṇụa inscription) while, at the same time, accounting for social mobility and their aspirations to political power. The metaphor of the root suggests that, even though it was not manifest or visible, the kșatriya identity of the family was integral to its public persona, and perhaps even its origins, just as the root is to the vine. That it is Bandhusena who is associated with the origins and growth of the metaphorical vine could indicate his central role in the evolution of the lineage and its kșatriya identity.

23 For [...]kaikabandhunā we could supply ekaikabandhunā. Gopal leaves the compound untranslated. Gopal (1985), 87. There is a potentially relevant parallel in the Kirātārjuniya: smaraikabandhu ('the only friend of the god of Love'). Since this verse describes the change of seasons and the beautiful ambiance of early spring (i.e. the cool season) with its blossoming flowers, it could be relevant in the context of an inscription which commemorates a temple to Kāma and the joys of his Spring Festival.

katipayasahakārapușparamyas tanutuhino 'lpavinidrasinduvārah /

surabhimukhahimāgamāntaśamsī samupayayau śiśirah smaraikabandhuh //10.30 //.

24 It is not clear from the fragmentary text how best to relate this compound to the rest of the verse since it is unclear whether it refers to the king Mayūravarman or to Skanda. We have opted to read it as a tatpurușa, but it could also be read as a bahuvrihi. In his translation of verse 6-which reads: "He was anointed in the kingdom by the immortal ... freshly blossoming lotus with music of the groups of female bees"-Gopal has opted not to connect the compound syntactically to an agent. Gopal (1985), 87 .

25 The text reads kungavarman. We have adopted Gai's emendation since Kangavarman is the spelling used in other epigraphic sources, such as the Tạlaguṇ̣a record.

26 The reference here to "limbs of sovereignty" recalls the discussion in the Arthaśâstra about the seven constituents of the kingdom (i.e. king, minister, countryside, fort, treasury, army, 
tatsuto bhagìratho nāmnā niyatam [...6...] manorathah / nrpatir āsīt satyatāśauryyagāmbhīryavidyākalānvitah // 8 //

8. His son was the king named Bhagiratha constantly the desire of $[\ldots]$, endowed with honesty, heroism, generosity, (and skill in) the arts and sciences. ${ }^{27}$

\section{śrimato bhagīrathasya suto raghur āsa rājāparājitah /}

ripugaṇaih samparāyamukhe raghusattvavikrāntidhïguṇah // 9 //

9. The son of the venerable Bhagiratha was Raghu, an unconquered king in the forefront of battle with his enemies, he possessed the virtues of goodness, valour, and wisdom like Raghu.

tatkanișthaś śrīkadambakulalalāmabhūto [...7 ...] /

narapatį̣ kākutstha ity āsa kākutsthavat sattvadhïgunaị // 10 //

10. His younger brother, the banner of the glorious Kadamba line, was the lord of men, Kākutstha—like Kākutstha (i.e. Rāma) with his virtues of wisdom and courage.

tasya sūnuś śāntivarmmeti nāmnā prajāsáñntaye 'bhavat / kșitipatir bhūvadhūtilako bhūmiśvarebhyo guṇādhikah // $11 / /$

11. His son was called Śāntivarman, who existed for the sake of the peace of the people. The lord of the earth - the auspicious mark (tilaka) on the forehead of his bride, the Earth-he possessed virtues superior to those of other earthly rulers.

tatsuto mrgeśanāmā $[\ldots 17 \ldots]$ /

mrgapatiprabhāvasattvavapur mrganäthalīlo viśäm patih // 12 //

ally). The Manusmrti 9.294 calls them "saptāngam rājyam." See Olivelle (2013), 6.1.1-6.1.18; pp. 271-273.

27 The description of the ruler as vidyākalānvitah recalls the list of the 64 arts $(k a l \bar{a})$ and sciences (vidyā) enumerated by Vātsyāyana in the Kāmasūtra 1.3.16. As Daud Ali explains, the acquisition of these skills was an indication of social cultivation and distinction for rulers and members of court, both male and female. Ali (2006), 75-77. 
12. His son was named Mrgeśa, the lord of people with the power, courage, and body of a lion (and who was) graceful like a lion [...].

samabhavan mrgeśaśābanibho jagatipates tasya dhìmataḥ / ravir iva svanāmatulyavapuḥ kaikeyaputryāṃ suto 'naghah //13 //

13. That wise earth lord had a son like a lion cub with the daughter of Kaikeya. ${ }^{28}$ He was faultless, like the Sun, with an appearance that was equal to his name: Ravi.

yo nihatya viṣnudāsanrpa $[\ldots 15 \ldots]$ /

prāpa rājyam bālya evāṣțādaśamaṇḍalimaṇ̣itam prabhuh // 14 //

14. He, the lord, having slain the ruler Viṣnudāsa [...] obtained sovereignty while still just a child (sovereignty that was) adorned by its control of the 18 circles. $^{29}$

svātmasattvavyomasambhūtalakṣmīndulekhānavāmbudam /

bālarājaṃ saṃyuge sabalam yo nìtavān mrtyuvaśyatām // 15 //

15. He led Bālarāja — a fresh cloud over the crescent-moon of fortune that arose in the sky of his own courage-along with his troops to the control of death in battle. ${ }^{30}$

vinayasampadā śrutena ${ }^{31} \operatorname{san} \bar{a}[\ldots 15 \ldots] /$

praṇatanașțabhìtasāmantā vavrdhe ca lakṣmīs tathā tathā // $16 / /$

28 We are told more about the identity and virtues of Mrgeśa's wife, Prabhāvatī, in the fifth century stone inscription from Tālaguṇạa. See Gai (1996), no. 13 .

29 In the Arthaśa astra, the 18 -fold circle consists of a ruler seeking conquest, the ally, and the ally's ally, together with their five respective constituents-i.e. minister, countryside, fort, treasury, and army. See Olivelle (2013), 6.2.13-24; p. 274.

30 Verse 15 begins a long description of the evolution of Ravivarman's political career and of his kingdom. The poet moves from a description of his youth-with poetic allusions to newness and freshness - to his education based on śastra in verse 18, and, finally, to a description of his total control of the earth in verse 20.

31 To complete the word beginning with sana $[\ldots]$ we could perhaps supply sanātana or a similar term meaning 'constantly' to express his consistent dedication to learning. 
16. His fortune, expanded ever more by the excess of his good conduct and his learning $[. .$.$] (due to which) the subordinate rulers bowed, were destroyed, or$ terrified. $^{32}$

\section{astraśaktitomarāpāstrakunteșu nișțhām parāṃ gatah /}

turagavidyārūụhamatir bāhyaś ca yo na dvipeșv api // 17 //

17. He achieved a state of total mastery in arrows, spears, lances, javelins, and pikes. His mind had ascended to the science of horses; and even knowledge of elephants was not beyond him.

yā ca nītir viṣnuguptakrtā subandhu[...11...] /

adhijagāma yas tayor nișțhạ̣̄ lokadvayodbhūtibhāvinìm // 18 //

18. He acquired mastery of both the political wisdom authored by Viṣnugupta, [and, likewise, that of] Subandhu, which promotes the elevation of both realms (i.e. the political and the religious). ${ }^{33}$

upanatā hi gañgapunnātakonigālapāṇdyālupādayah /

yasya cājñām bibhrati prītyā bhūmyātmadaṇ̂̄ārtthasañcayaị //19//

32 Gopal interprets this verse as a description of Ravivarman's benevolence and kindness to his subordinates. He translates: "The modest, soft, learned Ravivarman became prosperous by destroying the fear of the subordinates." His rendering of pranatanaștabhitasāmantā leaves 'pranata' (bowed) untranslated so it is unclear how this compound can describe Ravivarman as one who "destroys the fear of the subordinates". Gopal (1985), 88.

33 Viṣnugupta is understood to be one of the names attributed to the author of the early recension of the Arthaśāstra, along with Cānakya and, most well-known, Kauțilya. More specifically, the name Viṣnugupta is mentioned in the Nitisāra of Kāmandaka and is given along with Cānakya and Kauțilya in the Mudrārākșasa. On the authorship and author names connected with the recensions of the Arthaśāstra, see the 'Introduction' pp. 31-38 in Olivelle (2013). According to the Jain-inflected telling of the story of Cānakya/Viṣnugupta, the latter was employed in the court of king Bindusāra. Subandhu was his opponent in court and allegedly killed him and subsequently became a Jain monk. On this account, see Trautman (1971), 22-26; Lefeber (1993), 189-206. As Peter Bisschop has observed in a recent review, current scholarship on the Arthaśästra and its redactional history has not taken note of the reference to Viṣnugupta and his Nìti in the Guḍnāpur inscription. See, Bisschop (2020). 
19. The Gangas, Punnāṭas, Kongāalas, Pāṇḍas, Ālupas, and others who were subjugated, ${ }^{34}$ happily uphold his command through the accumulation of wealth produced by their own rule on earth. ${ }^{35}$

yasya cāpi mārutoddhatacaturarnavārnạo ${ }^{36}$ bhuvi /

tatra tatra sarpatā śucināyaśasā diśo varttanīkrtāh // 20 //

20. The four quarters of the earth were made into track(s) by his resplendent fame, spreading everywhere and [likewise] the waters of the four oceans tossed up by the wind $(?)^{37}$

dhvaṃsitetayo 'stabhītirasā yasmin svadharmmavyavasthitāḥ /
sukham avāpur dānabhogaratāḥ pitror ivāìnkasthitāḥ prajāh // 21 //

21. In whom the people-free from the taste of fear, their distress destroyed, (and) settled in their respective duties-attained happiness as if seated in the lap of their parents, delighting in the enjoyment of gifts.

34 The Gangas and Pāṇdyas are South Indian dynasties well-known from inscriptions. A reference to the Punnātas also occurs in the Candravaḷli Inscription of Mayūraśarman in the list of dynasties conquered by that king. See Gai, no. 2. Sircar identifies Punnāta with the Puṇnạdu region in southern Mysore district. Surviving copper plates of this dynasty portray them as allies of the Gangas. See, Sircar (1939), 245-246. The Âlupas were located in the western coastal region of what is now Karnataka and are known from epigraphical references, including the c. fifth-sixth century Halmidi inscription. On this inscription, see Gai (1996), 26; Suvrathan (2013) 25, 279. About the Kongālas we have found little information. Gai identifies them with the Kongālvas and remarks that the Guḍnāpur Inscription is the earliest reference to them. See, Gai (1996), 34 .

35 Alternatively, we might read the final compound as a dvandva and understand that the subordinate rulers upheld Ravivarman's command 'through (gifts of?) land, their own army, and masses of wealth.' Gopal translates that they "follow his instructions in acquiring land and money, income from danda (fines)". Gopal (1985), 89.

36 The ending of arnavo as reported by Gai and Gopal is difficult to interpret. There may be a problem with the text.

37 The meaning of this verse is not entirely clear. In addition to the issue described in n. 36 , the compound varttanikrtāh is also difficult to construe. The sense seems to be that the four quarters of the earth are pervaded by the king's fame up to the four oceans. Gopal understands varttanīkrtāh as "made as a path", which aligns with our translation. His translation of the rest of the verse is difficult to understand. "His pure fame made all directions as its path, around the four oceans, wandering around, cleanliness and fame being roused by groups of air". Gopal (1985), 89 .

Although the Kadambas do develop their own unique modes of expressing sovereignty, this geographic metaphor recalls claims made by their northern contemporaries, specif- 
saṃsprśáanti bhūvadhūpatayo nādyāpi lakșmīlatātaroḥ / śauryaratnadyotino ${ }^{38}$ yasya gunabhūṣaṇānām kalām api // 22 //

22. Who is a tree for the vine of fortune. Even today, shining as he does with the jewel of heroism, the husbands of the Earth bride do not touch even a tiny fraction of the ornaments of his virtues. ${ }^{39}$

yasya puṇyanimnagā bandhur ${ }^{40}$ durggam ca yasyoru pārvvatam ${ }^{41}$ / tena veśma manmathasyedạ̣ ravinā kṣitīndreṇa kāritam // 23 //

23. By this lord of the earth, Ravi, whose ally is the river of his merit, and whose mountain fortress is large, this dwelling of Manmatha was commissioned.

dakṣine 'sya rājavāsagṛhạ̣ vāme tathāntahpurollāsitam / nrttaśäle dve punas saumye prāgbhāgam āśritya vișțite // 24 //

24. To the right of it [i.e. of the temple] is the royal palace and on the left the women's chamber shines forth. In addition, there are two pleasant dancing halls placed in front.

\section{kusumagandhavāhibhiś śiśirair dhṛtihāribhir ddakșinānilaiḥ / yatra șaṭpadōvalīdhūmaḥ sandhukṣyate manmathānalah // 25 //}

25. [This temple] where the fire of Kāma-which has smoke in the form of rows of bees - will be kindled by the southern breeze, cooling, conveying joy, and which carries the scent of flowers. ${ }^{42}$

ically the geopolitical claims to a sovereignty that extends across all four quarters of the earth expressed in Samudragupta's Allahabad Pillar Inscription. See, Fleet (1888), no. 1.

38 Gai, Gopal, and Balogh read -dyotinā which syntactically qualifies bhüvadhüpatayo. We have emended to read-dyotino so that this compound qualifies yasya and thus better suits of the meaning of the verse, which is to exalt Ravivarman.

39 The temporal specification adyāpi could indicate that at the time of the record's composition Ravivarman was already advanced in age; yet, despite his senior status, his numerous virtues set him apart from younger rulers.

40 Gai, Gopal, and Balogh read bandhor. We have emended the text to bandhur.

41 Gai and Gopal read urupārvvatam as a compound.

42 The poetic image and association of Kāma with the perfumed Southern breeze, bees, and flowers is expressed in very similar terms in Dāmodaragupta's Kutțanimata. Goodall and Dezső (2012), v. 299; p. 129. This work also contains a description of a theatrical performance of the festival of spring and summarizes scenes from another poetic composition, Harșa's Ratnāvalī, which depicts the festival of Kāma as mentioned in the inscription, a 
api ca phullareṇudhūsarito rativigrahacchedadakșinạ̣ /

yatra kāmayuddhasannāhapațahaḥ kaḷm rauti kokilaḥ // 26 //

26. And where the Kokila bird-(whose body is) made dusky with flower pollen, (and who) is skilled at resolving quarrels born of passion-calls softly [like] a drum in the arsenal of the battle of love.

\section{tatra cittajanmano jagataḥ sthitisaṃkșayotpattikārinah / sthāpito madhau madhau ${ }^{43}$ lokanayanāravindotsavo mahah // 27 //}

27. There, the festival was established for the Mind-Born god-who effects the creation, destruction, and maintenance of the universe - in the first month of every spring, a feast for the lotus-eyes of the people.

\section{yadi na yujyate mahas tu madhau kuryyān nrpo mādhave 'thavā /} sambhaved yadā tadā kāryah kālāvadhiś śreyasāvadhị̣ // 28 //

28. But if the festival is not fitting in the first month of spring, the king should undertake it in the second month (Mādhava), or else it should be done when it is possible. The condition of time is (equal to) the condition of happiness. ${ }^{4}$

time of joyous dancing, song, and festivals. (v. 881-928; pp. 3350-349). The descriptions of Kāma's Spring Festival as celebrated by the royal court in the Ratnāvalī express the sense of joy and celebration of the fecundity of spring that is also suggested in the verses of the inscription. The play also refers to different modes of worshipping the deity Kāma. For example, in one scene the queen venerates an image of the deity and this practice elicits surprise from her maid, in whose home Kāma is worshipped in a painting. See Act 1 in Kale (1925). References to Kāma temples (kāmadevāyatana) also appear in the Pādātā taka (1.83) and the Padmapräbhrtaka (3.88), two plays that date to the c. fifth century. In these works, the Kāma temples appear in the urban setting of Ujjain and are places associated with courtesans and their devotional practices. The proximity of the Kadamba Kāma temple to the women's quarters within the palace context echoes the link with courtesans in these contemporaneous literary sources. For these plays, see Dezső and Vasudeva (2009), 38-43; 265 .

43 In verses 27 and 28 , the poet repeats the word 'madhau' (in spring) as a way to connect the two verses. On this convention in Sanskrit poetry, see Salomon (2016).

44 The second 'avadhi' in päda d is the proposed reading by Gai that we have adopted. The sense of the phrase is that the condition of time (i.e. the normal condition under which a ritual or festival is performed) is, in this case, when it is pleasing or conducive to wellbeing and happiness. It is not made explicit under what conditions the festival would not be celebrated. We might assume that astrological factors and the selection of as auspicious day in the ritual calendar would guide the decision. In this interpretation, the king is able to decide which time is most favorable for the celebration. This condition seems 
bhagavato madanasya niryāṇe kāryānuyātrā mahīkṣitā /

yadi na vesyate na nirbandhạ sarvās sukhārthā yataḥ kriyāh // 29 //

29. At the time of the procession of the Lord Madana, ${ }^{45}$ the king should accompany the procession; or if he does not perform (it) there is no requirement since all rituals are for the sake of happiness. ${ }^{46}$

anena nayanābhirāmam apadiśya cetobhuvo

gṛham ruciravastu bhūpatisukhaișinā kāritam /

itah prabhrtirakșaṇe 'sya sukhakirttidharmmaipsavah

pramāṇam avaniśvarās samayadharmmarakșāparāh // 30 // (Pṛthvī)

3o. He commissioned the abode of the Mind Born god (Kāma), a brilliant structure that was a pleasure to behold, out of a desire for the welfare of kings. From now on, future kings who aspire to pleasure, fame, and piety, and who are committed to upholding the terms of the conventional law, ${ }^{47}$ are the authorities with regard to its [i.e. the temple's] protection.

\subsection{Prose Section (Lines 17-27)}

(17) athāsya kāmadevālayasya püjāsaṃskārārttham asau mahārājaśrīravivarmmā ị̣iūragrāmam kāntārāryapāțīkallañgoḍagrāmam mogūrugrāmasīmni dakṣine guddatațākam bandhayitvā tasya tațākasyodakena yāvan nișpadyate tāva(18)d abhinavakșetrañ ca datvā punar imāni brahmadeyakșetrāṇi mahāveṅguligrāme vatsakakoțan nāma kșetram tasmin rājamānena dvādaśanivarttanapurānakșetran tasyottarata sthalañ ca caturvimśatinivarttanam $[1]^{48}$

Now, the king Ravivarman, for the sake of the ceremony of worship at the temple of Kāmadeva, [after giving] ${ }^{49}$ the villages Iḍiūra, Kāntārāryapāțī, (and)

especially fitting in the context of Kāma worship, which is presented as a celebration of joy and pleasure.

45 On the festival of Kāma depicted in literary sources see Meyer (1937).

46 Like verse 28 , this description of the procession emphasizes the flexibility of the ritual requirements. The poet does not explain what factors might influence the ruler's decision to accompany the procession (e.g. astrological conditions, personal preference, etc.)

47 On samaya-dharma as 'convention', see Davis (2004), 822 .

48 The numbers 1-9 given in the prose section do not correspond to verses or lines, but to the individual donations given as brahmadeyas by Ravivarman and they are included in the inscription. These numeral signs are also marked in Gopal's edition (1973), 68.

49 To make sense of this section of the inscription, we have chosen to read the gerund datva 
Kallanggoda, (and) after constructing the Guḍda Tank on the southern side of the village Moguru, gave as much newly cultivable land as can be irrigated with the waters of that tank.

In addition, he gave these fields as gifts of cultivable land to brahmins:

1. In the village of Mahāvenguli, the field called Vatsakakoța (and) the old field there 12 nivartanas ${ }^{50}$ by the royal measure and, to the north of that, 24 nivartanas of land.

kallan்gọ̣agrāmasīmny eva olukkīhalañ ca (19) kodravavāpakșetraparyantam [2]

2. Olukkihala at the border of Kallangoda village, and the adjoining field of Kodravāpa.

ị̣iūragrāmasyāpi sìmni brahmadeyakșetram ekam [3]

3. Also one field as a gift of cultivable land to brahmins at the border of Idiūra village.

dahrakavenguligrāmaś ca [4]

4. And the village of Dahrakavenguli. ${ }^{51}$

[...] kambigrāme esarāpagā paratīrapravāhaniṣpadyamāna kṣetraṃ ${ }^{52}$ veśmasthānañ ca tațākādhaś caturnivarttanamātram [5]

5 . And $[. .$.$] in the village of Kambi, a field and a place for houses, being irrigated$ by the stream flowing from the western bank of the Esarā River, measuring 4 nivartanas, south of the tank.

distributively and understand that the king gave both the three villages mentioned in this section of prose (i.e. Iḍiūra, Kāntārāryapāțī, and Kallangoḍa) as well as the new land that was created by his excavation of the tank. This reading also aligns with the interpretations of Gai and Gopal.

50 It is difficult to say what precise area nivartana as a measure of land corresponded to in the early Kadamba kingdom, since this differed across time and place. See Sircar (1966), s.v. "nivartana." That the nivartana was an official, standardized distance in the Kadamba kingdom is clear from the reference to the royal measure, rājamāna.

$5^{1}$ Here we understand that the entire village was a brahmadeya.

$5^{2}$ We read kșetram for kșetra. 
navanadyaparatīre (20) yāvat sopānakoddeśas tāvat sīmā cāsyottarato mahāpathah brhattațākaketakī-prasravaṇapadmatațākodakanișpadyamānakantatsamīpajātaif ${ }^{53}$ pușpaphalopabhogais tarubhị saha edekaṃ̣esamjñakañ ca kșetram [6]

6. And the big path to the north, as far as is indicated by the steps at the other bank of the Navanadya, thus is the boundary; and the field known as Eḍekaṃ̣e-irrigated by the water from Padmatatāka that flows from the Ketaki River into the Great Tank — together with its trees, enjoying flowers and fruits, growing in the vicinity of Kantat.

satturagrāme ca kșetram | (21) rājamānena pañcanivarttanam puvvāsikakhandena bhattaprasthena ca saha [7]

7. And the field in Sattura village, 5 nivartanas in extent by the official measure, together with Pullāsikakhanda and Bhattaprastha.

tasminn eva grāme anyac ca șaṇnivarttanam kṣetram samānyam sapanasavṛikșañ ca [8]

8. And in that very village another field of 6 nivartanas, the same size as the others but with jackfruit trees.

ambilakuṇ̣̂tațākasya paścimadiśa śṣngāt prabhṛti daśanivarttanaṃ purātanakṣetram | ataf parañ ca pukkolikșetram kṛtākṛtan tasya kșetrasya parimānam pūrvvāśādakșināásayām kammakūrasimāsamsthā uttarāśāyām esalanadīsamsthā [9]

9. The old field, 10 nivartanas, starting from the top, to the west of the Ambilakunda tank; further, Pukkoli field, including cleared and uncleared land. The measure of this field, to the east and to the south, ends at the boundary of Kammakūra, and to the north it ends at the Esala River.

evam etāni navabrahmadeyadeyakṣetrāṇi satāmraśāsanāni brāhmāryahastebhyax ${ }^{54}$ krïtvā dattavān (22)

53 The ' $f$ ' designates the upadhmānìya.

54 The ' $x$ ' designates the jihvāmūlìya. 
Line 22. Thus, after purchasing these nine fields, he gave them as land grants to brahmins, together with the copper-plates, into the hands of the honorable brahmins.

[23] ... ca parīkșya kșetrasya ca krtān maulyāt bahvadhika- [24] maulyam datvāa brahmacāribhyaś ca ... atha ca rājadușțạn kūțaśāsanakartrn cāturvvidyāsama[25] kṣamādāya idam aśobhanavaivi ... sthaiś ca parīkșya teșām sarvasvaharaṇe ... | [26] häkinipallị̣ kāmadevālayasya pūjāsaṃskārārtham kallïligrāmam padmāvatyālayasya pūjāsam skāāārtham mukūṇdya- [27] nvayāya sarvvanamasyam ... lokapiśācah nityavistīrṇnatușta

\subsection{Summary of Lines 23-27:}

The concluding prose section of the inscription is badly damaged and, as a consequence, particular sections are difficult to construe meaningfully. In lieu of a full translation, we have provided a summary along with the text below. The fragmentary lines 23 and 24 record the sale of, what we presume to be, the aforementioned brahmadeya plots by brahmacarins at a price higher than usual. The name of the person who purchased the tracts of land is lost but it is plausible that it was the king, Ravivarman. Roughly contemporaneous copper-plate inscriptions from the historical region of Pundravardhana in present day northern Bengal (ca. fifth-seventh century CE) record similar instances of the sale and subsequent donation of plots of land, referred to as khilakșetra. ${ }^{55}$ Sometimes the buyers were brahmins who purchased the land for their own use. In other cases, the petitioners were not brahmins themselves but were rather officials or rural landed elites like the grämika or vișayapati who then donated the plots to brahmins, sometimes in return for ritual services rendered. ${ }^{56}$

The surviving portions suggest that these lines include further details about the transactions of land detailed in the previous sections and may have also

55 Yamazaki (1982); Furui (2020), 42-46. Unlike in the Guḍnāpur pillar inscription however, these inscriptions from Bengal were not issued by individual rulers but by a local official body referred to as adhikarana in response to petitions from buyers. The transactions recorded are usually as follows: the adhikarana assents to the sale of plots assessed according to the akșayanivi $\bar{c}$ or nividharma tenures in return for payment in money from either individuals or collectives. There have been discussions amongst scholars about how best to understand khilakșetra. An important characteristic of khilakșetras, whether fallow or uncultivated wasteland, seems to be that they are usually located on the outskirts of villages. In any case the distinctions between fallow and uncultivated wasteland appear to be shifting, with formerly cultivated land quickly turned into forested areas as described in the Damodarpur plates. See Yamazaki (1982), 20-21; Furui (2020), 43.

Yamazaki (1982), 18-19; Furui (2020), 42-44. 
included some prohibitions against transgressing the authority of the grant. Lines 23 and 24 indicate that, following an examination, a price for a field was given to a group of brahmacārins that exceeded the value of the land. Line 24 continues with a warning that the manufacture of fake deeds is a crime against the king. ${ }^{57}$ This prohibition may have been followed in Line 25 with further details about the punishment for such a crime or additional regulations concerning the proper management of land grants. ${ }^{58}$ There are instances of forged copper-plate land-grants from the contemporaneous Vākāțaka kingdom, located to the north of the early Kadamba domain. These include the third plate of the Pandhurna copper-plate inscription and the Belora plates, both donations of revenue-exempt land to brahmins allegedly issued by the Vākāțaka ruler Pravarasena II (ca. mid-fifth century CE). The reference to copper-plate records as well as prohibitions against forgery in this early Kadamba inscription is further evidence that by the end of the fifth century CE copper-plate land-grant records had emerged as translocal, accepted documentary proof of possession in land and revenue-exemption from the state..$^{59}$

Lines 26 and 27 introduce two new donations of land: the village of Hākinipalli was given to support worship at the Kāma temple and the village of Kallili to support worship at the temple of Padmāvatī ${ }^{60}$ The mention of a temple to this goddess, popular within Jain communities, aligns with other inscriptions that clearly indicate the prominence of Jainism in the Kadamba polity. ${ }^{61}$ Line 26

57 This fragmentary mention about the crime of false documentation of land grants recalls the prohibition against false testimony regarding land—one of the gravest sins according to Manusmrti 8.99.

$5^{8}$ These prohibitions and warnings suggest that forged documents were not uncommon in this period. In fact, starting in the fourth century CE copper-plate records of royal land-grants began to be authenticated in various ways. These included the inclusion of formulae like drsțam at the beginning of records as well as the addition of seals with engraved legends to bind or literally 'seal' copper-rings that held the plates together. Salomon (2009).

59 Gomes (2017): 129-133. There is also epigraphic evidence from the mid-seventh century $\mathrm{CE}$ that copper-plate land grant records were periodically examined by state officials. See Salomon (2009): 108 for the example of the Madhuban copper-plate inscription of Harșa that describes how a brahmin was dispossessed of his land when the copper-plate inscription put forth as documentation was found by officials to be forged.

6o On the worship of Padmāvatī and related goddesses, see Singh (2008), 56-6o. It is interesting that the fragmentary portion of text following the reference to this goddess seems to suggest that worship of her is connected in some way with piśācas.

61 For example, the corpus of copper plates from Halsi records a series of endowments to Jain temples and religious specialists. On the Halsi Plates see Fleet, (1870, 1877); Bisschop and Cecil (forthcoming). The prevalence of Jainism in the Kadamba realm also prompted Gopal and Rao to interpret Kāmadeva as a reference to Bahubali of the Jain tradition. We, 
also mentions the lineage of Mukundi, which may be a proper name that indicates the identity of the donors of these villages. The fact that this lineage is identified at the end of the record suggests that they were affiliates of the royal family or officers of the court who, while not rulers themselves, held positions of social prestige and were thus considered worthy to include in the inscription. Finally, the last line includes a curious mention of piśācas who are gratified or satisfied by the 'spreading' of something, presumably a kind of offering that is associated with the Padmāvatī temple mentioned just before. ${ }^{62}$ In her study of the representation of Jain lay devotion at Ellora, Lisa Owen stresses Padmāvatīs efficacy in protecting devotees against demons (pretas, bhütas, etc.) as recorded in tenth-twelfth century inscriptions. ${ }^{63}$ The Guḍāpur inscription may well be a much earlier attestation of a connection that becomes fully developed in the medieval worship of this goddess. ${ }^{64}$

\section{4}

The Guḍnāpur Inscription and Early Kadamba History

The early Kadamba polity was the earliest kingdom to emerge in what is today Karnataka, and one of several successor states that emerged in the Deccan after Sātavāhana rule ended in the early third century CE. ${ }^{65}$ As is the case for many pre-modern dynasties in South Asia, most political histories of Kadamba rule rely on evidence from epigraphic texts. ${ }^{66}$ Find-spots of inscriptions suggest that early Kadamba authority was concentrated in west and central Karnataka and, to a lesser extent, in southern Karnataka and northern

however, see no evidence that supports this association. On this point see also Rao (1978), $37-38$. This publication includes a report and summary on the inscription, but no excavation reports have yet been published.

62 The mention of piśäcas in the context of temple worship recalls the contemporaneous copper plates issued from Bāgh by the Valkhā king Bhuluṇạa. These charters include donations for the maintenance of a variety of deities-Nārāyaṇa, the Mātṛs, Skanda, Bappapiśācadeva, and Indrasena. The editors, Ramesh and Tiwari, offer the plausible hypothesis that "piśāca" may indicate the soul of a person who had met with an unnatural death and Bappa Piśāca may represent the soul of the father of the lady Bandhulā who had the memorial installed. See Ramesh \& Tiwari (1990), xiii.

63 Owen (2012), 125-129.

64 This hypothesis is supported by Suvrathan's observation that the iconography of the central image, dated to the period between the tenth and the twelfth centuries CE, in the Kali temple in Iduru village close to Guḍnāpur is similar to the Jaina goddesses Padmāvatī and Jwalamalini. See Suvrathan (2014b), 221 and Figures 15a, 15b.

65 Sircar (1939), $215 \mathrm{ff}$.

66 J.F. Fleet (1882); Moraes (1931); Sircar (1939); Gopal and Tharanatha eds. (1996). 
Kerala. ${ }^{67}$ Kadamba power was dispersed across these regions where, as indicated by inscriptions, different branches of the lineage ruled concurrently, but not always peacefully, from regional capitals that included Banavasi (ancient Vaijayantī), Halsi (ancient Palāśikā) and Uccangidurg (ancient Uccaśrnngī). ${ }^{68}$ Sometime towards the end of the sixth century CE, their rule ended and the region passed into the control of the Cālukyas of Bādāmi. No inscriptions associated with the early Kadambas from the post seventh-century CE period have been found. Since its discovery, scholars have highlighted the Guḍnāpur inscription's importance as a source for recovering early Kadamba dynastic history and chronology. ${ }^{69}$ More specifically, the record constructs a full genealogical account spanning ten generations that builds on the earlier Tâlagunḍa inscription's narrative about the transformation of the Kadambas from a lineage of brahmins to a powerful ruling family (this is discussed in greater detail below). The genealogy culminates with praise of Ravivarman, the current ruler at the time of the record's composition and the ruler who presided over the Kadamba polity at the height of its power when the southern territory with its capital at Vaijayantī was united with the northern capital of Palāsikā.

Inscriptions served as critical tools for royal representation and selffashioning in premodern South Asia and commemorated acts of piety and giving to religious institutions. While a full discussion of the role of the religious landscape of the Kadamba polity is beyond the scope of this study, a consideration of the variety of donations made by the rulers, along with their public-facing brahmin identity and lineage, raises a number of questions about the use of epigraphic records to identify the religious affiliations or identities of premodern political figures. While it is clear that rulers self-identified and chose to associate themselves with particular communities as a political strategy, our challenge is to understand what particular donations may tell us about regionally embedded religious traditions and communities and how affiliations with such communities supported the Kadamba political agenda. Expressed in another way, the question of the religious affiliations of the donors and recipients may reveal less about the function of donations and temple

\footnotetext{
67 Suvrathan (2014b), 206.

68 The Nilambur plates from Ravivarman's fifth regnal year record the donation of two villages to a brahmin named Govindasvāmin. The inscription ends with the warning that whoever tries to wrest the land away from Govindasvāmin, whether a member of the Kadamba family or someone else, is guilty of the five great sins. This suggests early in Ravivarman's reign, Kadamba rulers fought amongst themselves over territory in northern Kerala where the inscription was found. See Rao and Rao (1905-1906), 146-149; Gopal (1985), 6o-63; Gai (1996), 94-95.

69 Gopal (1973), 64-66; Gai (1996), 7, 17-18, 33-37.
} 
endowments than the details or nature of royal participation in those donative events. The Guḍnāpur inscription is a critical historical source for thinking about this question of royal participation since it provides details about the location, setting, and ritual events surrounding the royal Kāma temple and its endowment typically lacking from donative records, which often employ scripted or idiomatic formulae to describe the dynamics of royal giving.

While the Guḍnāpur pillar inscription has been interpreted as a textual source for dynastic and religious histories of the early Kadambas, previous studies have tended to read its text in isolation from the particular religious and political landscapes in which it was embedded. One notable exception to this trend in Kadamba studies is the recent work of archeologist Uthara Suvrathan, whose work considers early Kadamba inscriptions as part of the regional archaeological assemblage. ${ }^{70}$ Through a systematic archaeological survey of a 5 o sq. kilometre area surrounding Banavasi and Guḍnāpur, her study suggests that Banavasi was a 'peripheral core' on the margins of larger empires from the first to the eighteenth centuries CE. Banavasi thrived as a regional political center, the study argues, because it was a place where local ruling elites, like the early Kadambas, legitimized their rule through patronage of religious shrines and communities. While Suvrathan's work has certainly provided new longue durée perspectives on political and religious organization outside of dynastic histories, it relies upon the analytic of legitimation to understand the early Kadamba rulers' patronage of brahmins and Jain institutions through land-grants. ${ }^{71}$

Our study, by contrast, complicates the use of legitimation as an explanatory tool by examining the specificities of early Kadamba royal patronage of religious establishments and their interventions in the agrarian economy. Ravivarman's inscription shows how early Kadamba rulers communicated and materialized their authority through monumental texts that recorded patronage of religious institutions and by shaping the agrarian landscape and regional economy through land-grants to brahmins. As seen through the inscription, the formation of the early Kadamba polity was the work of multiple social processes and agents: religious communities and institutions, agrarian expansion, temple-centered festivals, monumental architecture, and Sanskrit texts.

70 Suvrathan (2013), (2014a), (2014b).

71 Suvrathan (2013), 246-248; (2014a), 121-122; (2014b), 240. 


\section{$5 \quad$ Physical Landscapes of the Guḍnāpur Pillar Inscription}

Guḍnāpur was a settlement located five kilometres to the north-west of Banavasi, the modern name for the ancient Kadamba capital of Vaijayantī. Recognized for its eponymous picturesque lake, in the fifth and sixth centuries CE, Guḍnāpur was part of the religious and political arena centred around Banavasi.

Banavasi's history can be traced back to the early centuries CE before Kadamba rule when it first emerged as a fortified settlement. The BanavasiGuḍnāpur region has a long history as a space claimed by multiple, and sometimes competing, religious communities, as evinced by Jaina basadis, Śaiva temples, Lingayat shrines, as well as shrines to local deities like the goddess Chowdamma. A number of early stone structural temples survive in the area, yet practices of rebuilding and reuse in the contemporary period make these structural remains difficult to date precisely and to determine what portions may be contemporaneous with the early Kadambas. Most existing temples, including the well-known Madhukeshwara temple at Banavasi, for example, can be securely dated only to the period after $1000 \mathrm{CE} .{ }^{72}$

The landscape of Banavasi and Guḍnāpur is also replete with traces of local religious traditions and non-Brahmanical practices. ${ }^{73}$ These local cults often did not make monumental interventions in the form of structural temples and thus their traces in the landscape can be difficult to contextualize. Such traces include $n \bar{a} g a$ stones found throughout Banavasi, even within the precincts of the Madhukeshwara temple. One of these năga-stones can be dated as far back as the first century CE based on an inscription engraved on it. Several stone sculptures of female figures, perhaps depictions of the goddess Hāritī have also been found in and around Banavasi. ${ }^{74}$ Hāritī is known from various sources including inscriptions issued by regional rulers starting with the Cuțu Sātakanis, to the early Kadambas, as well as rulers of the Cālukya dynasty, who all identify themselves as 'sons of Hāritī' (häritīputra). Verse 2 of the Guḍnāpur inscription describes the Kadamba rulers as 'sons of Hāritī' as part of an

72 While some architectural and structural elements of the Madhukeshwara temple may be attributed to the seventh or eighth centuries $\mathrm{CE}$, most of the temple as it exists today is architecturally dated to the post twelfth century CE period. This chronology is also supported by inscriptions on temple walls. See Suvrathan (2013), 99-103; (2014b), 211-218. teenth century CE and attests to the reinterpretation and re-use of shrines in the region, and perhaps also competition between religious communities. See Suvrathan (2013), 107. Suvrathan (2013), 115-117, 120-121; (2014b), 219-220. 
idiomatic epithet repeated in subsequent epigraphic records. Matronymics were common epithets for rulers in the Deccan and were adopted by rulers of the Sātavāhana, Ikṣvāku, and Vākāțaka dynasties. The invocation of the goddess in the Deccan and South Indian sources suggests her widespread popularity as a protective emblem for rulers in Brahmanical contexts as well. Given the popularity of Hāritī as evidenced by these multiple sources, it has been suggested that the epithet Hāritīputra as adopted by rulers in the Deccan should not be understood as a traditional matronymic but rather as an indicator of royal devotion to the deity Hāritī. ${ }^{75}$

Archaeological excavations at Guḍnāpur conducted by the Archaeological Survey of India (ASI) in the 1980s-199os revealed brick and laterite block structures next to the now abandoned Virabhadra temple. These structures were part of a building complex that the ASI dated between the fifth and sixth century centuries CE and which they identified with the Kāma temple, royal residences, and dancing halls mentioned in the pillar inscription. ${ }^{76}$ It has been noted, however, that this dating and identification is not secure. Based on finds of flat and multi-cusped roof tiles from the early historic period as well as late medieval black-and-red ware, the architectural complex had a much longer occupational history that spanned multiple political regimes. Some parts of the complex, however, can be dated to the early historic period and surface ceramic scatters found at Guḍnāpur support this suggestion. ${ }^{77}$

\subsection{Agrarian Landscapes and the Kadamba Polity}

In addition to memorializing Ravivarman's act of piety, the Guḍnāpur pillar inscription also records significant details about land transactions and the role of the rulers in administering the regional agrarian landscape. These transactions, recorded in prose beginning at line 17 of the inscription, are in the form of land grants and royal endowments of villages and agricultural tracts to the Kāma temple as well as to brahmins. ${ }^{78}$ These donations also include Ravivarman's order to construct a tank and donate the lands irrigated by its waters to the Kāma temple. That the donation of the tank, and the consequent expansion of irrigation and cultivation that it assumes, is recorded alongside land

\footnotetext{
75 Trautmann (1972), 12.

76 Suvrathan (2013), 73 .

77 The early historic period in southern India is dated between the late centuries BCE and the seventh century CE in Suvrathan (2013), 73-74, 81-82.

78 As Bhat's (1978) study of the geographical data of the inscription has shown, the contemporary toponyms and water features of the regions surrounding Guḍnāpur preserve a legacy of Kadamba interventions in the regional landscape.
} 
donations to the Kāma temple is an explicit statement of political investment in agrarian expansion and royal sponsorship of temple-centered ritual activity through land donations.

It is not made explicit in the text how Ravivarman's individual gifts of land to brahmins were connected to the Kāma temple or to the occasion of its endowment, but it is likely that they were offerings made on the occasion of a festival or other significant ritual event tied closely to the establishment of the monument. It is also interesting to note that in line 22 the text specifies that after he had purchased the lands, the king gave them to the brahmins together with the copper plates (tämraśäsana), which likely included details of the privileges and exemptions that were accorded to the recipients of the nine brahmadeyas. This indicates that, in addition to recording the gifts in the public pillar inscription, these donations were also commemorated via a second epigraphic medium, presumably to function as deeds and transactional records held by the individual recipients. ${ }^{79}$

In fact, the earlier Tālaguṇạa pillar inscription of Śāntivarman (ca. fifth century) illuminates a history of state investment in expansion of irrigation and support for religious institutions in the early Kadamba kingdom. ${ }^{80}$ Śantivarman's orders are engraved on a granite octagonal pillar and pillar-base, 11 feet high in total, currently standing in front of the Pranaveśvara temple at Tălagunda in the Shimoga district of Karnataka. The inscription begins with three verses that pay homage first to Śiva referred to as Sthānu, then to brahmins, and, finally, a verse in glorification of king Kākusthavarman. After an elaborate and poetic narration of the history and genealogy of the early Kadamba dynasty, verse 33 of the inscription documents the excavation of a great tank at the behest of Śāntivarman's predecessor, the king Kākusthavarman, at the temple of Bhava (i.e. Siva) for the supply of abundant water. Thus Ravivarman appears to be drawing on and extending a tradition of early Kadamba kings excavating tanks within temple precincts as public acts of piety.

79 Some early historic Sātavāhana inscriptions engraved on cave walls at Nasik refer to land transactions involving Buddhist renunciants being recorded on plates of either copper or cloth ( pațika). These include Gotamiputa Sātakani's inscription from his eighteenth regnal year (ca. 1st century CE) and Vāsițhiputa Puḷumāvi's record from year 22 of his reign (ca. 2nd century CE). Sircar (1965b), 108. The dates in the inscription refer to the day on which recipients of the donations received pațikas as records of the land transactions. Sir$\operatorname{car}(1965 a), 83,87$; Mirashi (1981), 11, 19. These early historic records thus attest to a longer history of states documenting land transactions involving religious institutions and individuals on both fixed stone surfaces as well as more portable media like copper plates.

Kielhorn (1905-19o6), 24-36; Gai (1996), 64-68. 
Lines 18 to 22 of the Guḍnāpur pillar-inscription list Ravivarman's gifts of multiple tracts of land. ${ }^{81}$ These tracts are designated as brahmadeyas granted in perpetuity and exempt from a range of taxes. ${ }^{82}$ Notably, one of the earliest epigraphic uses of the term brahmadeya appears in an inscription connected to the early Kadambas, namely the Malavaḷli pillar-inscription of Hāritīputra Viṇhukaḍ̣̣a Cuṭukulānanda Sātakaṇī. ${ }^{83}$ The Cuṭukulānda Sātakarṇis emerged as rulers of the region in and around Banavasi after Sātavahāna power waned in the Deccan and prior to the emergence of the early Kadambas. Apart from inscriptions, finds of coins issued by rulers with names ending -ānanda found near Banavasi and in the Uttara Kannada district also attest to the existence of these rulers. ${ }^{84}$ The name, Viṇhukaḍda Cuṭukulānanda Sātakaṇī, suggests that rulers of this new polity, far more restricted in geographic scale than the previous Sātavāhana state, may have been a branch of or a lineage once subordinate to the Sātavāhana dynasty. This is suggested by amongst other things, echoes in name where many rulers of the Sātavāhana dynasty were called Sātakaṇi. ${ }^{85}$

Viṇhukaḍḍa Cuṭukulānanda Sātakaṇīs pillar inscription is currently located in front of the Kalleshwara temple in Malavalli, 7o kilometres south-west of Banavasi, in the Shimoga district of Karnataka. The inscription, written in epigraphic Prakrit, is engraved on a hexagonal six-foot-high column of black stone. Like the Guḍnāpur pillar inscription studied here, the three lines of this inscription wrap around the entire pillar and should be read from the bottom to the top. ${ }^{86}$ The record begins by paying homage to the deity, bhagavann Malapali. It then conveys the order of the king of Vaijayantì, Sātakanì, who was of the Mānavya gotra and a son of Hāritī. The order is addressed to the official, the rajjuka, named Mahāvallabha, and records the ruler's gift of the grāmahāra of Sahalātavī to someone named Koṇuamāna for the "enjoyment of the god

$81 \quad$ Plots of land are usually called kșetra in the inscription. In line 18 however, a plot named Olukkī on the border of Kallangoda village is referred to as a hala, literally meaning 'plough.' The term hala, in inscriptions of roughly this period can be understood as a metonym for agricultural land. See Sircar 1966, s.v. "hala." See also the Patagandigudem plates of the Ikṣvāku ruler Ehavala Cāntamūla (r. ca. 250-30o CE) for an earlier attestation of "hala" meaning agricultural land. Falk (1999-2000); Baums, Griffiths, Strauch and Tournier (2020), 55 .

82 Meaning a gift to brahmins, the term brahmadeya in inscriptions between ca. 30o-60o CE refers to the land-tenure system whereby brahmins, either individually or in groups, received tracts of land or villages from rulers. Sircar (1966), s.v. "brahmadeya."

83 Rice (1902), Sk. 263; Lüders (1912), No. 1195; Mirashi (1981), no. 35; Gopal (1985), 5-7.

84 Bhandare (1998), 294.

85 Sircar (1939), 2; Bhandare (1998), 297-298.

86 Mirashi (1981), 87. 
Malapali (malapalidevabhoga)." ${ }^{87}$ The gift, designated as a bahmadejja (Sanskrit brahmadeya) was accompanied by all exemptions including the privilege that soldiers were not to enter the donated area. ${ }^{88}$

What connects this inscription to the early Kadambas is a 5 -line inscription of an unnamed early Kadamba king engraved on the same pillar (early fourth century CE). ${ }^{89}$ The early Kadamba inscription echoes and builds upon Cuṭukulānanda Sātakanii's inscription in several ways. First, the early Kadamba record, like the older inscription, also begins with salutations to the deity Malapali. It then documents an order by the unnamed early Kadamba king to renew Śivakhadavama's endowment. Śivakhadavama is described as lord of Vaijayantī, of the Mānavya gotra, and as a son of Hāritī. The inscription does not mention the dynasty to which this previous ruler of Banavasi, Śivakhadavama, belonged. However, it is clear from epithets that the early Kadamba king who renewed the endowment saw himself as related to Sivakhadavama. Thus, the early Kadamba ruler, the dharmamahāräjādhirāja, the lord of Vāijayantī, like his predecessor, belonged to the Mānavya gotra and was a son of Hāritī (hāritīputa) $\cdot{ }^{90}$

The renewed endowment by the early Kadamba ruler recorded on the pillar comprised thirteen villages that are named in the inscription. The list includes Sahalā, a village that may be identified as Sahalātavī, donated previously for the deity Malapalī. The recipient of this gift of thirteen villages was named Nāgadatta who belonged to the Koṇuamānā lineage. Judging from this lineage name, it is likely that Nāgadatta was a descendant of Koṇ̣amāna, who was the

87 Translation after Mirashi (1981). Sircar (1939), 250 interprets grāmahāra to mean a group of villages. The functions of the officials rajjuka or rajjuka-gāhaka-amacca are mentioned in multiple sources including Aśokan inscriptions and Jātaka narratives. The rajjuka was a high ranking official whose duties were concerned mainly with land-revenue collection and administration as well as the construction and upkeep of public works like roads. See Sircar (1939), 251.

88 Mirashi interpreted the term sasiddhika that also appears in the inscription as a privilege associated with the bahmadejja donation as the "right to adjudicate disputes."

89 Rice (1902), Sk. 264; Lüders (1912), No. 1196; Gopal (1985), 3-5; Gai (1996), 59-6o. According to Sircar (1939), 223, the language of this inscription is similar to the language of the Mayidavolu and Hirahadagalli plates of the early Pallava ruler Śivaskandavarman. Sircar $(1939,223-224)$ suggests that the inscription was issued by Mayūravarman while according to Gai it should be attributed to a predecessor of Mayūravarman. Gopal's interpretation $(1985,4)$ on the other hand follows Lüders to understand Śivakhadavama as the name of the early Kadamba king. See also Sircar (1939), 249 n. 1.

9o The epithet dharmamahārājādhirāja also appears as a title for the Pallava ruler Śivaskandavarman in the Hirahadagalli inscription and Sircar (1939), $248 \mathrm{n}$. 1 suggests that the early Kadamba ruler adopted Śivaskandavarman's title. 
recipient of the bahmadejja/brahmadeya gift of Sahalātavī. ${ }^{11}$ Both Koṇuamāna and Nāgadatta may have been part of the hereditary line of brahmins associated with the deity Malapalīs shrine. The final echo between the two records is with regard to the exemptions and privileges that accompanied the endowment. The donation here is also categorized as a bahmadejja and the inscription records that the thirteen villages were accompanied by all exemptions (savaparihära) including the exemption from soldiers entering the villages (abhat $a$ pavesa). ${ }^{92}$

These two closely connected inscriptions suggest that the brahmadeya tenure had a long history in the early Kadamba realm; this history can be traced back to the early fourth century CE. They also suggest that brahmadeya donations were connected to brahmins, presumably acting as ritual specialists in the shrines, who received not just land in the form of villages and agricultural tracts, but also fiscal and juridical exemptions and privileges. Finally, the Malavalli inscriptions specify that the land-grants were meant for the enjoyment (bhoga) of the god, which indicates that the revenue generated from the donations was likely used to maintain Malapalīdeva's shrine and fund ritual worship. Ravivarman's brahmadeya donations should thus be understood in light of this longer history of brahmadeya donations by the Kadambas.

\section{Rhetorical Landscapes of the Guḍāpur Pillar Inscription}

The Guḍnāpur pillar inscription demonstrates how rulers, even of regional kingdoms like the early Kadamba polity, exercised political control through built landscapes. In Ravivarman's case, this control was manifest through the construction of the Kāma temple at Guḍnāpur, as well as investments in agrarian expansion through the excavation of a tank and land-grants to the temple and brahmins. What is important to highlight is that the exercise of power through the royal engineering of regional landscape was commemorated through inscriptional praise poetry, praśasti. In the Tạlaguṇ̣a inscription, for example, Śāntivarman, by whose command a tank was excavated, is described as "the auspicious mark (tilaka) on the forehead of his bride, the Earth." Similarly, the Guḍnāpur pillar inscription celebrates Ravivarman's shaping of both

$91 \quad$ Sircar (1939), 250, 25 o n. 1.

92 Gopal (1985), 5. The term samsiddhika appears in this inscription as well. Unlike Mirashi who understood the term as connected to juridical privileges, Gopal translated it as "fully prepared." It is unclear what Gopal meant by "fully prepared" when understood in the context of exemptions and privileges associated with the brahmadeya land-tenure system. 
the physical and imaginative landscapes of the Kadamba kingdom and, in doing so, presents him as the greatest ruler of the Kadamba lineage.

As mentioned in the introduction, the text of the inscription encircles the monument from bottom to top. The specific placement of these lines raises questions about the performative aspects of the text-monument. Was the inscription meant to be read from the pillar in an act of circumambulation? ${ }^{93}$ If so, who would the audience for this event have been? Along with individual acts of viewing, people might have heard the inscription being read out aloud or perhaps even sung out loud as part of a ritual event. The text may have also been performed on special occasions like the Spring Festival described in the inscription. And who would be granted direct access to the royal monument? Given that the pillar was part of a royal residential and temple complex, it is a strong possibility that access to the column was restricted. Even for those literate few who were allowed to approach the pillar, it would have taken time and effort to read the 27 lines wrapping around the 20 -foot-high pillar. The column would also have conveyed a wide range of meanings to those seeing it, even if they were not hearing or reading the text engraved on it. For instance, the pillar may have been 'read' as a towering commemoration of Ravivarman's generosity: his construction of the tank at Guḍnāpur and support to the Kāma temple and brahmins through land-grants. ${ }^{94}$

Who these listeners and readers may have been is difficult to determine using the surviving evidence. We may plausibly assume that they included members of the ruling and elite classes in the early Kadamba kingdom and beyond. Listeners, viewers, and readers may have also included non-royal members of the religious community surrounding the Kāma temple: dancers, ritual specialists, temple functionaries, and worshippers. Thus, although the pillar lay felled, partially buried, and ostensibly forgotten when B.R. Gopal encountered it, Ravivarman's orders engraved on the monument would have marked a significant and meaningful intervention in the royal complex for those who experienced it during and after his reign.

93 For a discussion of the public recitation and performative aspects of epigraphic texts in premodern South India see Padma Kaimal (2016), 159-207.

94 The Guḍnāpur pillar thus participated in the widespread use of columns as multivalent monuments and tools for political self-representation. For comparable examples from Gupta period North India, like the Allahabad pillar of Samudragupta and a discussion of the range of meanings that inscribed columns materialized in early India, see Cecil and Bisschop (2019). 


\subsection{Genealogy and Lineage Identity}

The poet responsible for the Guḍnapur inscription presents a complex vision of kingship that aims to reconcile an idealized brahmanical piety with the ethos of ksatriya valor. Bringing these two ideologies into conversation serves the larger aim of constructing a Kadamba lineage identity. This can be traced throughout their epigraphic corpus and in both stone and copper plate inscriptions. The genealogy is a standard feature within the genre of the royal praśasti, and is crucial for the presentation of coherent and authoritative lineage identity. ${ }^{95}$ Streamlined and organized, these genealogies typically present a stable line of direct succession in which one exemplary ruler is followed by another, each more ideal than the last. In the Kadamba corpus we can observe the creation of just such an idealized family tree. And while the rulers themselves aspire to ideals of kingship modeled on heroes from the lineage of Raghu, they also portray themselves as intimately connected to the regional landscape, a connection that is materialized through their acts of piety.

To fashion the royal persona of the Kadamba rulers, the Guḍnāpur pillar builds on the earliest expression of lineage identity presented in the narrative genealogy of the Tālaguṇụa Pillar Inscription. ${ }^{96}$ The Tālagunḍa epigraph introduces a genealogical frame and account of the origins of the Kadamba dynasty as descended from an illustrious lineage of brahmins. The transformation of the family from a lineage of religious specialists to a powerful line of kings is connected to the lineage progenitor, Māyuraśarman. According to verse 10 of the inscription, Māyuraśarman travelled with his 'guru' Vĩraśa$\operatorname{rman}^{97}$ to Kāñcī, the capital of the Pallava rulers, with the intention of entering a ghațika, an institution that Kielhorn understood to be a center of Vedic learning, but which may have had an economic function as well. ${ }^{98}$ After arriving there, he was involved in an altercation with a Pallava solider and, as the

95 On the importance of genealogy for epigraphic expressions of lineage identity see Ali (2000), (2006); Dezső (2021); Henige (1975); Pollock (2006).

96 The innovation of the Tạlaguṇu record is clear when compared with the earlier pillar inscription, and the first of the Kadamba rulers, from Malavalli, in which there is little attempt to construct a lineage.

97 In the Tālaguṇ̣a inscription, the precise relationship between Māyuraśarman and Vīraśarman is not specified. In the Guḍnāpur inscription Vīraśarman is presented as the grandfather of Māyuraśarman. The poet also includes praise of Vīraśarman's eldest son, Bandhuṣena, who is not mentioned in the Tālagunḍa record.

98 Kielhorn's translation of ghațikā was challenged in an article by Tieken and Sato (2000) who examined contemporaneous South Indian inscriptions to argue that the ghațikā was, in fact, a kind of customs-house where goods lacking official documentation could be charged duty or confiscated. Following their analysis, Māyuraśarman was employed there 
poet describes in verses 11-13, this conflict occasions a crisis of consciousness whereby he is unable to endure what he perceives as the marginalized status of brahmins vis-à-vis the warrior class. ${ }^{99}$ As the narrative continues in verses 1420, Māyuraśarman resorts to violence to combat this perceived injustice and becomes a renegade king operating on the margins of the Pallava Empire. Confronted with his undeniable bravery and martial skill, the Pallavas eventually accept him and grant him a territory on the western coast in verse 21. This poetic history charts a transformation in which the pious brahmin becomes a mighty king who rivals even the Pallavas, rulers who represent the old establishment of imperial ambition. While assuming a new social position, Māyuraśarman's eulogist consistently styles him as an outsider who resorts to the kșatra ethos only when necessary and only to defend his pious ideals. In this way, he remains a kind of heroic anti-hero embracing royalty on his own terms. The myth of Māyuraśarman's political ascendance at the Pallava court thus provides a compelling narrative that negotiates the tension between two social orders and plots a memorable account of Kadamba origins. In addition to this narrative, the Tâlagunda inscription also includes an explanation of the family's unique name, which derives from a legendary Kadamba tree that grew in the compound of the family home. Because they acted as its dedicated caretakers, they became known as Kadambas. ${ }^{100}$

The artful construction of Kadamba lineage identity in the Tālagunḍa inscription includes details that, while they serve rhetorical aims, also serve to humanize the rulers through reference to specific 'personal' details and situations tied to particular locales in the regional landscape. Two generations later, Ravivarman's Guḍnāpur inscription builds upon this earlier lineage, but the tone has changed significantly. The poet(s) of the Guḍnāpur record develop a eulogistic genealogy that presents a crystallized succession of rulers. The etiological details about the emblematic Kadamba tree and the affective dimensions of Māyurśarman's rise to political power have been elided. Instead, we are presented with a more robust and comprehensive line of kings that, unlike the Tālaguṇ̣a account, did not develop in a specific historical context or as a result of a chain of narrative events, but exists in a state of idealized atemporality.

as a tarkuka (a term Kielhorn translates with 'mendicant', but which Tieken and Sato take more literally as a record-keeper charged with estimating the value of certain kinds of goods).

99 Following their revised understanding of the ghațikā, Tieken and Sato (2000) interpret this altercation as a dispute over the value and ownership of Pallava horses; that is, horses that were the property of the kingdom but detained at the ghațikā.

100 Gai (1996), 65 v. 7-8. 
This gesture to a universal rather than a localized political identity participates in the idioms popularized by the Guptas. ${ }^{101}$

\subsection{The Religious Landscape of the Kadamba Polity}

The Kadamba epigraphic corpus records a wide variety of donations to a diverse range of religious groups and specialists. In one of the earliest Kadamba grants, the ca. third-fourth century pillar from Malavalli (mentioned above), an unnamed king ruling from Vaijayantì reinstates a grant made to the deity Malapalideva by an earlier ruler.102 The Tạlaguṇ̣a Pillar begins with an invocation of Siva (Sthānu) and records the excavation of a tank near the temple of a locally venerated manifestation of the deity. ${ }^{103}$ In addition, the rich corpus of Kadamba copper plates details donations to localized Jain and Buddhist communities as well as brahmin lineages. The set of seven plates from Halsi (Palāśikā) are particularly significant since they record royal investments in a particular locale over generations. ${ }^{104}$

In addition to dynastic history, the Guḍnāpur pillar inscription is also important for the unique details it reveals about religious history, in particular the devotion to and the institutionalized worship of the deity Kāma, also referred to as Manmatha in the inscription. ${ }^{105}$ While references to the deity Kāma, his temples, and descriptions of his Spring Festival are not uncommon in literary sources, ${ }^{106}$ the Guḍnāpur inscription is one of few that commemorates a temple to Kāma as a royal foundation. Moreover, the description of Kāma in verse 27 praises him not simply as a god, but as the ultimate theological reality and agent behind the creation, maintenance, and destruction of the world (jagatah sthitisamkșayotpattikārinah) using an idiomatic phrase typically reserved for the supreme deities of the Hindu pantheon: Brahmā, Viṣnu, and Śiva. The poet's eulogy of Kāma as a deity on a par with the established creator gods is a remarkable feature of the Guḍnāpur inscription, yet this point has not been taken up by either Gai or Gopal in their studies. One reason for this is a persistent misidentification of the Kāmadeva in the inscription as a Jain deity, more specifically Bahubali. This identification was introduced by Gopal in his 1973 edition of the text. Given that a number of other Kadamba records

\footnotetext{
101 On this feature of Gupta epigraphic self-fashioning see Cecil and Bisschop (2021); Pollock (2006), 240. On the sharing of political idioms and imitation as a mode of learning to being 'imperial' see Pollock (2006).

102 Gai (1996), 61-62.

103 Gai (1996), 64-68.

104 Gai (1996); Fleet (1870); Bisschop and Cecil (forthcoming).

105 Gopal (1973), 66-68; Sohoni (1983), 294-297; Gai (1996), 35-37, 47.

106 See n. 42.
} 
mention endowments to Jain temples, Gopal was puzzled by the description of Kāma as the ultimate deity in the Guḍnāpur inscription, since Kāma is not recognized as such in the Jain tradition. He then concluded that the deity in question must have been part of the Jain pantheon and, based on a reference in the Ādipurāna which lists Manmatha as one of Bahubali's epithets, Gopal concluded that the Kāmadeva of the inscription was, in fact, the Jain deity. ${ }^{107}$ As mentioned above, the description of Kāma in the Guḍnāpur record is unique, but there is no textual or material evidence to support a connection with Jainism. While Gopal's argument that the Kāma temple was a Jain institution is unsupported, his hypothesis that the pillar likely stood in front of the temple (suggested by the proximate pronoun in the phrase idam veśma) is plausible. Since such monuments were commonly styled as dhvaja-s or ketu-s, (i.e. monumental banners) that bore the emblems of the deity enshrined in the temple, we suggest that the Guḍnāpur pillar was a makara-dhvaja. ${ }^{108}$ The crowning element in question may have resembled the makara that adorned a makaradhvaja at Kausambi in North [Figure 3].

The presentation of Ravivarman's donation of the Kāma temple serves a rhetorical aim since it supports the larger project of styling him as an ideal sovereign exemplifying brahmanical piety, martial prowess, knowledge of statecraft, and a host of other virtues. The temple materializes aspects of this ideal sovereignty since this is a donation made explicitly by the ruler and in the

107 In addition to the reference from Pampa's Ādipurāna, Gopal also mentions that the Kāma temple is also known as käma-jinālaya. He gives no reference for this description and it is not present in the text. It may be the case that he is repeating a contemporary description or title given to the material remains that survive at the cite by the local people. This hypothesis seems to be confirmed by Bhat who mentions that there is an unexcavated mound in the village known as 'jainare katte' (mound of the Jains). This description would seem to preserve a long-standing association of the early Kadambas with the region's Jain religious landscape but it is not present in the inscription. See Gopal (1973), 66-67; Bhat (1978), 28-29.

108 Compare the description below of the circumambulation of the makara-dhvaja from the Pādātāditaka (see also n. 47): eșā hi purānapumścalī dharaṇiguptā nāma kāmadevāyatanād devatāyā upayācitam nirvartya sphuțitakāśavallariśvetam àgalitam aṃsadeśād upari keśa hastam vinyasyantī sadyodhautanivasanā vigalitam uttarīyam ekāṃse pratisamādadhānā balivikșepopanipatitair balibhṛtaih parivrtam mayūraṃ nrtyantam apāngenāvalokayantī makarayașțị pradakșin̄ikaroti "This is the ancient courtesan called Dhárani-gupta. She has petitioned the deity in Kama's temple, and now she circumambulates the Mákara-post, putting back on her shoulder her flopping hair, white as a blossoming sugarcane, wearing freshly washed clothes, replacing on her shoulder the cloak that has slipped down, and casting a sidelong glance at the dancing peacock surrounded by crows that alighted when the bali-offering was laid out." Dezső and Vasudeva (2009), 38-41. 


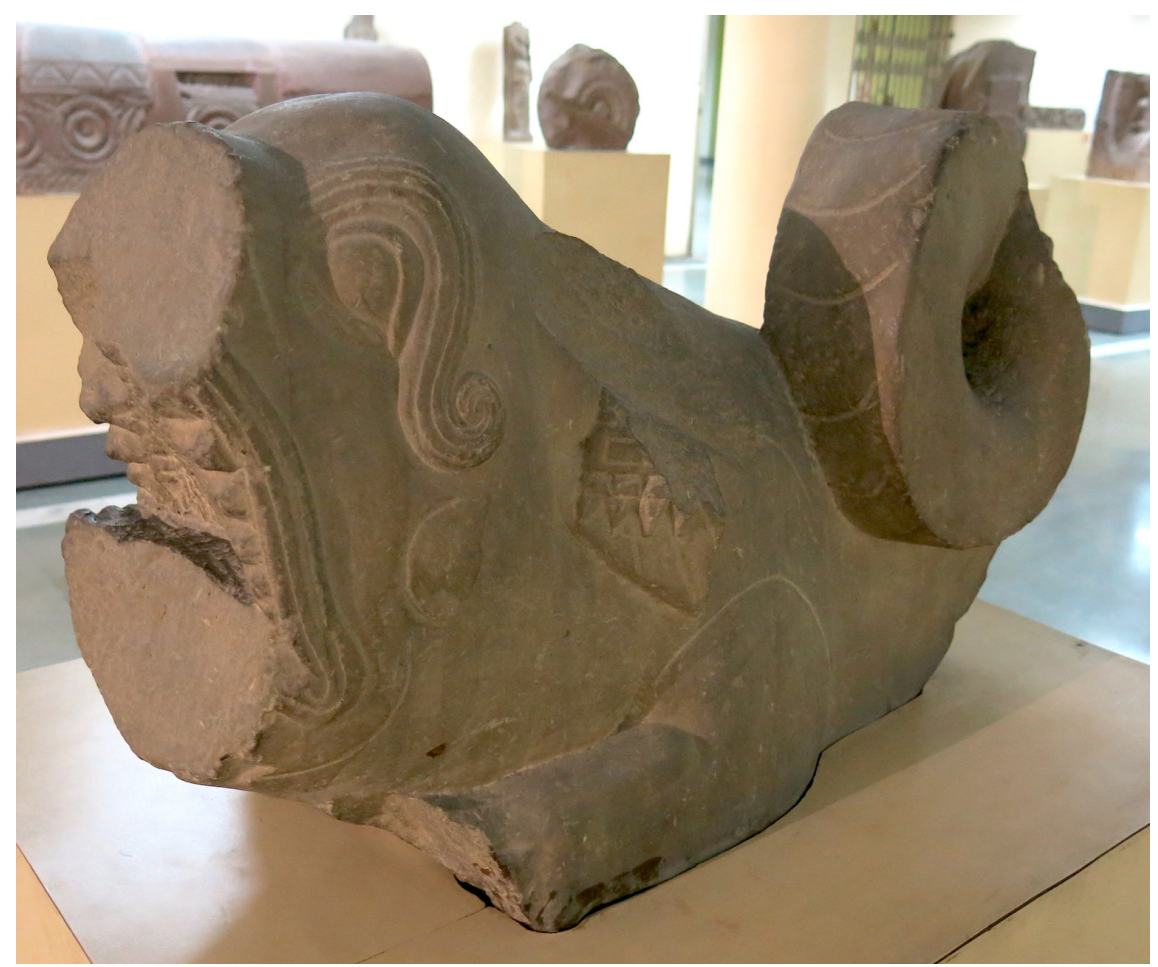

FIGURE 3 Example of makara column capital from Kausambi, Allahabad Museum AUTHOR Рното

vicinity of the royal residence and capital. It is described as an imposing and highly ornamented building, a symbol of wealth and control over resources which also, as we learn in the prose section, presides over a large number of donated villages, agrarian lands, and water resources. ${ }^{109}$ The descriptions of the temple also contribute a unique affective dimension to the presentation of Ravivarman's rule and his political persona by evoking emotions of joy, happiness, and the feeling of pleasure. Pleasure, experienced through various physical and aesthetic means, became an important facet of medieval court culture, ${ }^{110}$ and the Guḍnāpur inscription is significant as an early epigraphic construction of this dimension of courtly life and political persona that is also tied to the ritual and religious functioning of the polity. These facets are expressed in verses $27-30$ which describe the annual Springtime festival

109 On the political economy of land-donation in early South India see Heitzman (1997).

110 Ali (2006). 
of Kāma and the procession of the deity in remarkably flexible terms. While the majority of rituals mentioned in inscriptions are scheduled at particular times of day or auspicious moments in the lunar calendar, Kāma's festival, we are told, can take place at various times according to convenience and desire. The point of ritual, as the poet explains, is pleasure. Presumably, this emphasis on happiness as a motivation for ritual action is tied specifically to the worship of Kāma, about which we know relatively little. And, we are told, it was out of a desire for the pleasure and happiness of future kings that Ravivarman commissioned the temple. Finally, in verse 30 , the value of pleasure is evoked again as part of a triad including fame and piety. Rulers who aspire to attain these three (sukhakirttidharmmaipsavah) can do so through the proper maintenance of the temple.

\section{$7 \quad$ Conclusions}

The inscription on the Guḍāpur pillar illuminates multiple facets of the history of political formations at the dawn of the early medieval period in South Asia- a period associated with radical transformations in social, agrarian, and religious organization, political structures, as well as economic and urban processes. This essay positions the Guḍnāpur pillar within this broader historical context of social change to show how the inscribed object did not merely exemplify established religious and political patterns, but actively created new discursive traditions of political, religious, and agrarian landscapes in the early Kadamba kingdom. Many of the innovations associated with such epigraphic practices have been identified as products of North India and the 'classical' Gupta period. ${ }^{111}$ The Guḍnāpur inscription complicates this historiographical picture by providing evidence for conceptions and public projections of a royal identity that participated in established political idioms, while also expressing a locally inflected vision of lineage identity in a South Indian context.

\section{Acknowledgments}

We would like to thank the journal editors for their comments on earlier versions of this article. We are also grateful to the two anonymous reviewers for

111 See Cecil and Bisschop (2019); Bisschop and Cecil (2021). 
their careful reading and critical feedback. Their suggestions have resulted in significant improvements to our study. Finally, we thank Peter Bisschop for reading and discussing the inscription with us in Leiden.

\section{References}

Ali, Daud. 200o. "Royal Eulogy as World History: Rethinking Copper Plate Inscriptions in Cola India." Querying the Medieval. Texts and the History of Practices in South Asia, eds. Ronald Inden, Jonathan Walters, and Daud Ali, 165-229. Oxford: Oxford University Press.

Ali, Daud. 2004. Courtly Life and Political Culture in Early Medieval India. Cambridge: Cambridge University Press.

Balogh Dániel. 2017. "Guḍnāpur Inscription of Ravivarman." Accessed 19 July 2020. Siddham Database INO 1046, https://siddham.network/inscription/guḍnapur-grant -of-ravivarman/

Baums, Stefan, Arlo Griffiths, Ingo Strauch and Vincent Tournier, eds. "EIAD 55: Copper plates from Patagandigudem (Kallacheruvu), set I-reign of Siri-Ehavalacāntamūla." Early Inscriptions of Āndhradeśa, accessed 22 September 2020, http://hisoma .huma-num.fr/exist/apps/EIAD/index2.html.

Benton, Catherine. 2006. God of Desire: Tales of Kamadeva in Sanskrit Story Literature. Albany: SUNY Press.

Bhat, H.R. Raghunath. 1978. "Geographical Data of Guḍnāpur Inscription." Studies in Indian Epigraphy vol. Iv, eds. Ajay Mitra Sastri and S.H. Ritti, 26-29. Mysore: Epigraphical Society of India.

Bhandare, Shailendra. 1998. "Historical Analysis of the Satavahana Era: A Study of Coins." PhD dissertation, University of Mumbai.

Bisschop, Peter C. 2020. Review of The History of the Arthaśästra: Sovereignty and Sacred Law in Ancient India, by Mark McClish, Indo-Iranian Journal 63: 189-194.

Bisschop, Peter C. and Elizabeth A. Cecil. 2021. "Primary Sources and Asian Pasts: Beyond the Boundaries of the 'Gupta Period." In Primary Sources and Asian Pasts, eds. Peter C. Bisschop and Elizabeth A. Cecil, 1-17. Berlin: De Gruyter.

Bisschop, Peter C. and Elizabeth A. Cecil. (forthcoming). "Jayati Bhagavān Jinendrah! Jainism and Royal Representation in the Kadamba Plates of Palāsikā." Journal of the American Oriental Society.

Cecil, Elizabeth A. and Peter C. Bisschop. 2019. "Columns in Context: Venerable Monuments and Landscapes of Memory in Early India." History of Religions 58.4: 355-403.

Cecil, Elizabeth A. and Peter C. Bisschop. (2021). "Idiom and Innovation in the Gupta Period: Revisiting Eran and Sondhni." Indian Economic and Social History Review 58.1: 29-71. 
Davis, Donald R. 2004. "Dharma in Practice: Ācāra and Authority in Medieval Dharmasāstra." Journal of Indian Philosophy 32: 813-830.

Dezső, Csaba. 2021. "The Meaning of the Word ärya in Two Gupta-Period Inscriptions." In Primary Sources and Asian Pasts, eds. Peter C. Bisschop and Elizabeth A. Cecil, 269-277. Berlin: De Gruyter.

Dezső, Csaba \& Somadeva Vasudeva (eds. and trans.). 20o9. The Quartet of Causeries, by Śyāmilaka, Vararuci, Śūdraka \& İśvaradatta. New York: New York University Press.

Falk, Harry. 1999-200o. "The Pātagaṇ̣̣igūḍem copper-plate grant of the Ikṣvāku king Ehavala Cāntamūla." Silk Road Art and Archaeology 6: 275-283.

Fleet, J.F. 1870. "On some Sanskrit Copper-plates found in the Belgaum Collectorate." Journal of the Bombay Branch of the Royal Asiatic Society 27.9: 229-249.

Fleet, J.F. 1877. "Sanskrit and Old Canarese Inscriptions." Indian Antiquary 6: 22-32.

Fleet, J.F. 1882. The Dynasties of the Kanarese Districts of the Bombay Presidency from the Earliest Historical Times to the Muhammadan Conquest of A.D. 1318. Bombay: Government Central Press.

Fleet, J.F. 1888. Corpus Inscriptionum Indicarum, Vol. III. Inscriptions of the Early Gupta Kings and Their Successors. Calcutta: Government Printing India.

Furui, Ryosuke. 2020. Land and Society in Early South Asia: Eastern India 400-1250 AD. London and New York: Routledge.

Gai, G.S. 1958. "Kuntagani Plates of Kadamba Ravivarman, Year 12." Epigraphia Indica XXXII: 217-219.

Gai, G.S. 1961. "Banavasi Inscription of Vinhukada Satakanni, Year 12." Epigraphia Indica XXXIV: 239-242.

Gai, G.S. 1996. Inscriptions of the Early Kadambas. Delhi: Indian Council of Historical Research and Pratibha Prakashan.

Gomes, Mekhola Sophia. 2017. "Expressions of Power: Representations and Practices of Kingship beyond the Vindhyas.” PhD. dissertation, Jawaharlal Nehru University.

Gonda, J. 1956. "Ancient Indian Kingship from the Religious Point of View." Numen 3.1: 122-155.

Goodall, Dominic and Csaba Dezső. 2012. The Bawd's Counsel: Being an Eighth-Century Verse Novel in Sanskrit by Dāmodaragupta. Groningen: Egbert Forsten.

Gopal, B.R. 1973. "Guḍnāpur Inscription of Kadamba Ravivarma." In Śrīkaṇțikā: Dr S. Srikantha Sastri Felicitation Volume, 61-72. Mysore: Geetha Book House.

Gopal, B.R. 1985. Corpus of Kadamba Inscriptions. Volume 1. Sirsi: Kadamba Institute of Cultural Studies.

Gopal, B.R., and N.S. Tharanatha., eds. 1996. Kadambas: Their History and Culture. Mysore: Directorate of Archaeology \& Museums.

Henige, David P. 1975. "Some Phantom Dynasties of Early and Medieval India: Epigraphic Evidence and the Abhorrence of a Vacuum." Bulletin of the School of Oriental and African Studies 38.3: 525-549. 
Heitzman, James. 1997. Gifts of Power: Lordship in an Early Indian State. Oxford: Oxford University Press.

Kaimal, Padma. 2016. "Word-Image-Tango: Telling Storied with Words and Sculptures at the Kaillāsanātha Temple Complex in Kāñcīpuram." In Archeology of Bhakti II: Royal Bhakti, Local Bhakti, eds. Emmanuel Francis and Charlotte Schmid, 159-207. Pondicherry: École française d'Extrême-Orient.

Kale, M.R. 1925. The Ratnāvalī of Śrī Harsha Deva, 2nd ed. Bombay: Gopal Narayan \& Co.

Kielhorn, F. 19o6-19o6. “Tālaguṇụa Pillar Inscription of Kakusthavarman.” Epigraphia Indica 8: $24-36$.

Lefeber, Rosalind. 1993. "The Minister Cāṇakya, from the Pariśișțaparvan of Hemacandra." In The Clever Adulteress and Other Stories: A Treasury of Jain Literature, ed. Phyllis Granoff, 189-206. Delhi: Motilal Banarsidass.

Lüders, H. 1912. Appendix to Epigraphia Indica and Record of the Archaeological Survey of India, Vol. x: A List of Brahmi Inscriptions from the Earliest Times to about A.D.400 with the Exception of Those of Asoka. Calcutta: Superintendent Government Printing.

Meyer, J.J. 1937. Trilogie Altindischer Mächte und Feste der Vegetation, Erstes Stück. Kāma: Der Altindische Liebesgott als Vegetationsdämon und sein Fest. Zurich/Leipzig: Max Niehans Verlag.

Mirashi, V.V. 1981. The History and Inscriptions of the Sātavāhanas and the Western Kshatrapas. Bombay: Maharashtra State Board for Literature and Culture.

Moraes, George M. 1931. The Kadamba Kula: A History of Ancient and Mediaeval Karnataka. Bombay: B.X. Furtado.

Morrison, Kathleen D. and Mark T. Lycett. 1997. "Inscriptions as Artifacts: Precolonial South India and the Analysis of Texts." Journal of Archaeological Method and Theory 4.3: $215^{-237 .}$

Olivelle, Patrick. 2013. King, Governance, and Law in Ancient India: Kautilya's Arthaśāstra. Oxford: Oxford University Press.

Orr, Leslie C. 20o6. "Preface." In Pondicherry Inscriptions, compiled by Bahour S. Kuppusamy, edited by G. Vijayavenugopal, i-xxvii. Pondicherry: Institut Français de Pondichéry and Ecole Française d'Extrême-Orient.

Owen, Lisa. 2012. Carving Devotion in the Jain Caves at Ellora. Leiden: Brill.

Pollock, Sheldon. 2006. “Empire and Imitation." In Lessons of Empire: Imperial Histories and American Power, eds. Craig Calhoun, Frederick Cooper, and Kevin W. Moore, 175-188. New York \& London: The New Press.

Pollock, Sheldon. 2009. The Language of the Gods in the World of Men: Sanskrit, Culture, and Power in Premodern India. Berkeley: University of California Press.

Rao, M.S. Nagaraja 1978. Progress of Archeology in Karnataka: 1956-1972. Karnataka: Directorate of Archaeology and Museums. 
Ramesh K.V. and S.P. Tiwari. 199o. A Copper-Plate Hoard of the Gupta Period from Bagh, Madhya Pradesh. New Delhi: Archaeological Survey of India.

Rao, T.A. Gopinatha and G. Venkoba Rao. 1905-1906. "Nilambur Plates of Ravivarman." Epigraphia Indica VIII: 146-149.

Rowan, Jennifer Gilmanton. 2012. "Danger and Devotion: Hariti Mother of Demons in the Stories and Stones of Gandhara: A Historiography and Catalogue of Images." PhD dissertation, University of Oregon.

Rice, B. Lewis. 1902. Epigraphia Carnatica VII: Inscriptions in the Shimoga District, Part I. Bangalore: Mysore Government Central Press.

Ritti, Shrinivas and K.V. Ramesh. 1973. "A New Charter of Kadamba Mrigesavarman, Year 6." Epigraphia Indica XL: 109-112.

Salomon, Richard. 2009. “The Fine Art of Forgery in India." In Écrire et Transmettre en Inde Classique, eds. Gérard Colas and Gerdi Gerschheimer, 107-134. Paris: École française d'Extrême-Orient.

Salomon, Richard. 2016. "Concatenation in Kālidāsa and Other Sanskrit Poets." IndoIranian Journal 59: 48-80.

Sankalia, H.D. 1941-1942. "A New Copperplate Grant of Kadamba Ravivarma, 12th Year." New Indian Antiquary IV: 178-181.

Schopen, Gregory. 2013. "A New Hat for Hārītī: On "Giving" Children for their Protection to Buddhist Monks and Nuns in Early India." In Little Buddhas: Children and Childhoods in Buddhist Texts and Traditions, eds. Vanessa R. Sasson. Oxford, New York: Oxford University Press.

Singh, R.B.P. 20o8. Jainism in Early Medieval Karnataka. Delhi: Motilal Banarsidass.

Sircar, D.C. 1939. The Successors of the Sātavāhanas in Lower Deccan. Calcutta: University of Calcutta.

Sircar, D.C. 1965a. Select Inscriptions Bearing on Indian History and Civilization, from the Sixth Century B.C. to the Sixth Century A.D. 2nd ed. Calcutta: University of Calcutta. Sircar, D.C. 1965b. Indian Epigraphy. Delhi: Motilal Banarsidass.

Sircar, D.C. 1966. Indian Epigraphical Glossary. Delhi, Varanasi, and Patna: Motilal Banarsidass.

Sohoni, S.V.1983. "A Note on the Guḍnāpur Inscription of Ravivarman." In Śrīnidhih:Perspectives in Indian Art and Culture, Shri K.R. Srinivasan Festschrift, 293-298. Madras: New Era Publications.

Suvrathan, Uthara. 2013. "Complexity on the Periphery: A study of regional organization at Banavasi, c. 1st-18th century A.D.” PhD diss., University of Michigan.

Suvrathan, Uthara. 2014a. "Regional Centres and Local Elite: Studying Peripheral Cores in Peninsular India (c. First-Eighteenth Century CE)." Indian History 1. January: 89142.

Suvrathan, Uthara. 2014b. "Spoiled for Choice? The Sacred Landscapes of Ancient and Early Medieval Banavasi." South Asian Studies 30.2: 206-229. 
Tewari, S.P. 1985. "An Early Reference to Madana-Mahotsava in the Guḍnāpur Inscription of the Kadamba Ravivarman." Studies in Indian Epigraphy vol. XI, ed. S Subramonia Iyer, 25-32. Mysore: Epigraphical Society of India.

Tieken, Herman and Katsuhiko Sato. 200o. "The "Ghațikā" of the Twice-Born in South Indian Inscriptions." Indo-Iranian Journal 43.3: 213-223.

Trautman, Thomas R. 1971. Kauțilya and the Arthaśāstra: A Statistical Investigation of the Authorship and Evolution of the Text. Leiden: Brill.

Trautman, Thomas R. 1972. "Licchavi-Dauhitra." Journal of the Royal Asiatic Society 104.1: 2-15.

Trautmann, Thomas R. and Carla M. Sinopoli. 2002. "In the Beginning Was the Word: Excavating the Relations between History and Archaeology in South Asia." Journal of the Economic and Social History of the Orient 45.4: 492-523.

Yamazaki, Toshio. 1982. "Some Aspects of Land-Sale Inscriptions in Fifth and Sixth Century Bengal." Acta Asiatica 43: 17-36. 